\title{
CHANGES TO FOOD SERVICE WITHIN SUPER-REGIONAL SHOPPING CENTRES IN
} TORONTO

\author{
By \\ Brian Truong \\ Honours, Geographic Analysis (BA) \\ Ryerson University, 2018 \\ A Major Research Paper (MRP) \\ presented to Ryerson University \\ In Partial Fulfillment of the \\ requirement for the Degree of \\ Master of Spatial Analysis \\ in the program of \\ Spatial Analysis
}

Toronto, Ontario, Canada, 2019

(C) Brian Truong, 2019 


\section{Author's Declaration}

I hereby declare that I am the sole author of this MRP. This is a true copy of the MRP, including any required final revisions. I authorize Ryerson University to lend this MRP to other institutions or individuals for the purpose of scholarly research. I further authorize Ryerson University to reproduce this MRP by photocopying or by other means, in total or in part, at the request of other institutions or individuals for the purpose of scholarly research. I understand that my MRP may be made electronically available to the public. 


\title{
Changes to Food Services within Super-Regional Shopping Centres in Toronto
}

\author{
By \\ Brian Truong \\ Ryerson University \\ Master of Spatial Analysis
}

2019

\begin{abstract}
This research explores how the changes in food services have affected super-regional shopping centres in the Toronto Census Metropolitan Area between the years of 2014 and 2019. As shopping centres have begun to shift some of their operations away from traditional retailers and begun to invest in food services throughout the centre. The research examines seven food service categories and how each of them affect the overall trade areas of the shopping centre. Trade areas were created through a 60:40 weighting system for the attractiveness of each shopping centre, with $60 \%$ going to retail while $40 \%$ going to food services. The results of this study indicated that a growth in Fast-Casual, Gourmet Food, and Impulse food services across all shopping centres. While trade areas of shopping centres have seen mixed results due to the growth of food services.
\end{abstract}

Keywords: Food Services, Shopping Centres, Huff Model, Toronto 


\section{Acknowledgement}

I would like to thank my supervisor, Dr. Tony Hernandez for his guidance and support over the past three years. Dr. Hernandez has help me realize my potential through his undergrad course; Geodemographics and by allowing me to work at the Centre for the Study of Commercial Activity. I've learned a lot during my time at the Centre it would not be possible for me to be where I am today without the amazing people at the CSCA.

Throughout my graduate studies, Dr. Shuguang Wang has continued to push me to produce better results, and for that I am grateful to have his support. I would also like to thank my friends; Cody, Jennifer, and Selasi for going through the struggles of undergrad and grad school with me. My significant other, Promise has supported me from the first day I met her, I will always be thankful for the amount of patience she has showed me. Lastly, my family has given me the opportunity to become who I am today, without them I would not be here. I am endlessly grateful for everything they have provided me, and the support they have given. 


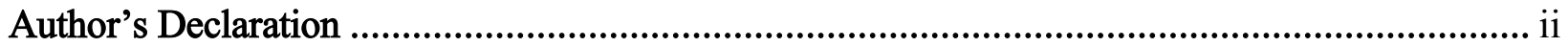

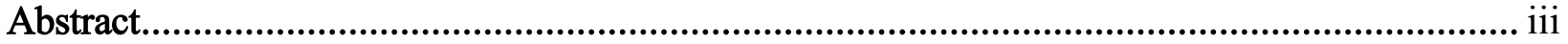

Acknowledgement ............................................................................................................... iv

List of Figures .................................................................................................................. vii

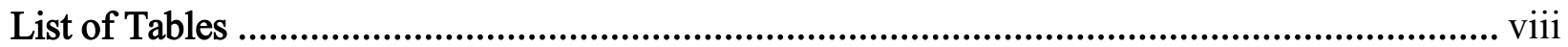

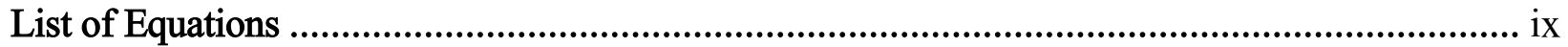

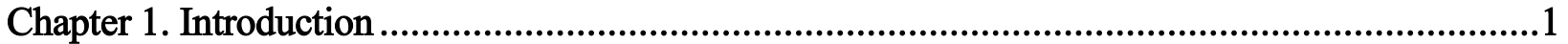

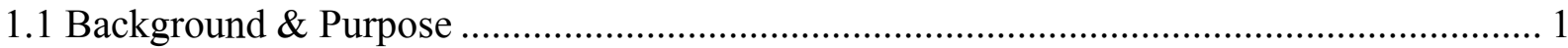

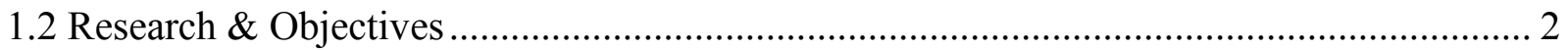

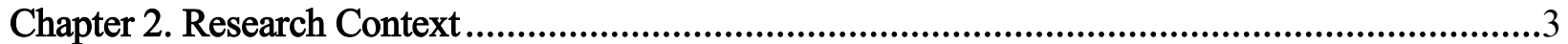

2.1 The Changing Landscape of the Traditional Shopping Centre ............................................ 3

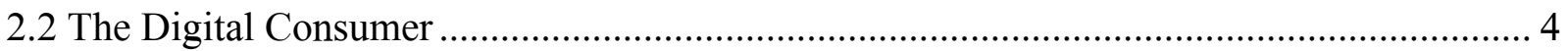

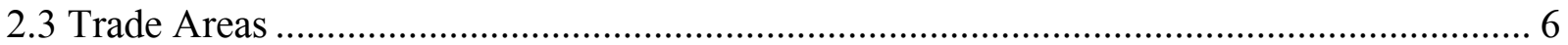

Chapter 3. Research Method \& Methodology ............................................................................

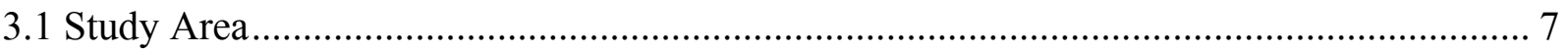

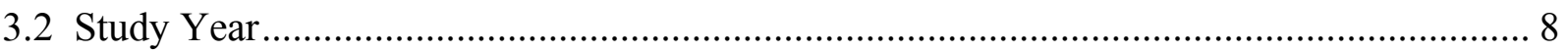

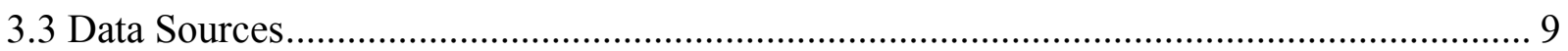

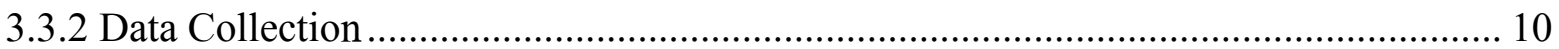

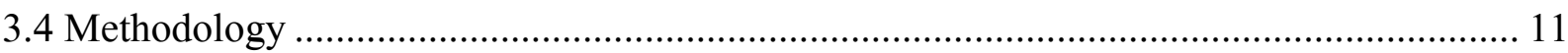

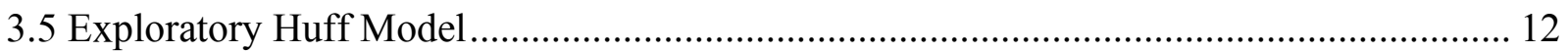

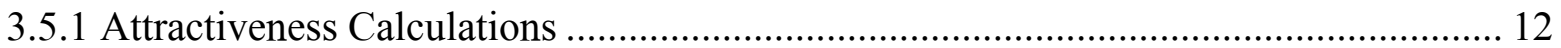

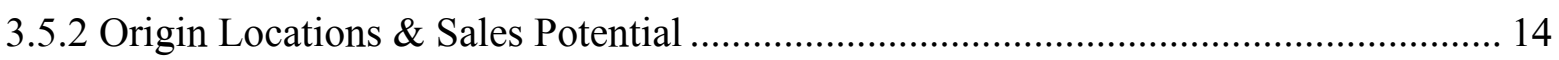

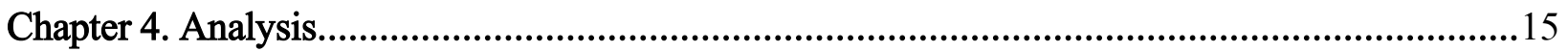

4.1 Changes in Food Services across Super-Regional Shopping Centres................................ 15

4.2 Trends in Shopping Centre Food Services ..................................................................... 16

4.3 The Impacts of Food Services on Shopping Centre Trade Areas ...................................... 20

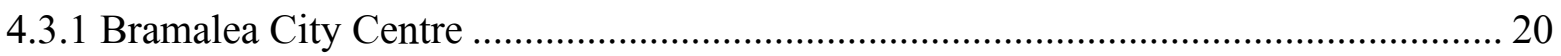

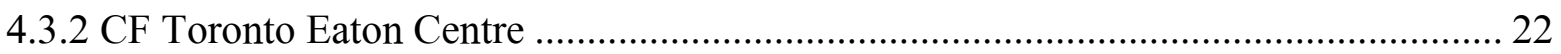

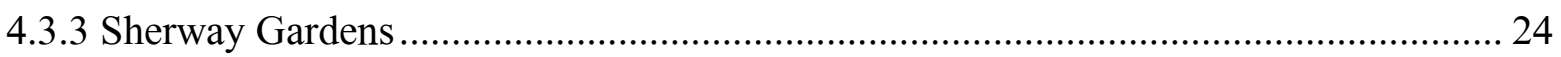

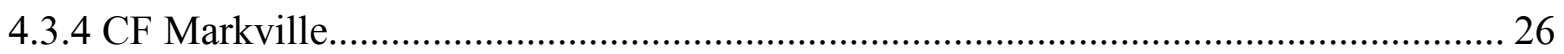

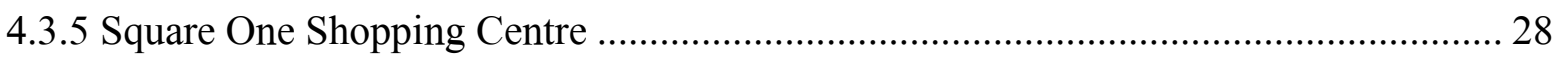

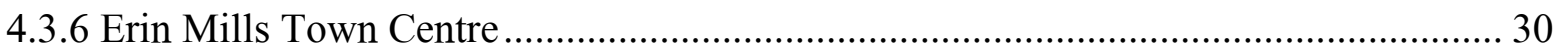

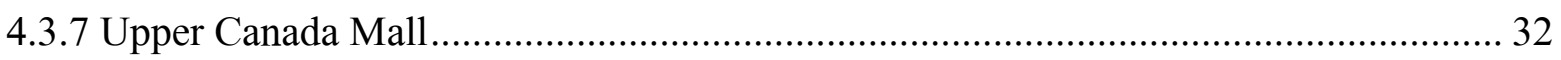




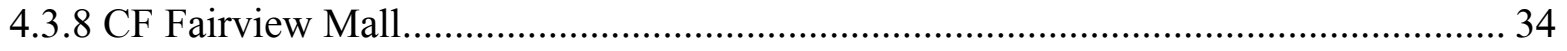

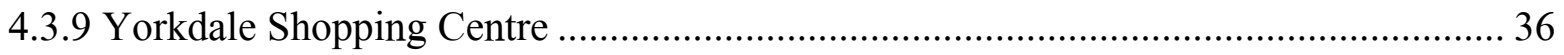

4.3.10 Scarborough Town Centre .................................................................................... 38

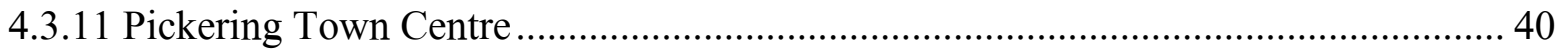

4.4 The Future of Food Services within Shopping Centres ............................................. 42

Chapter 5. Conclusion \& Future Research ..........................................................................43

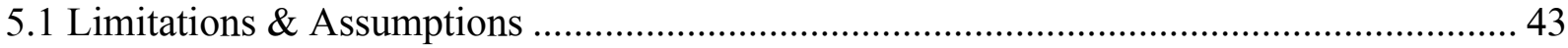

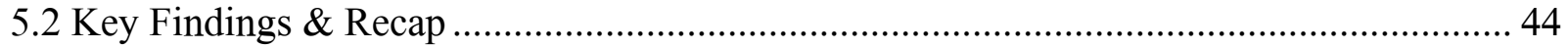

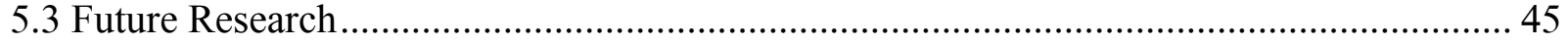

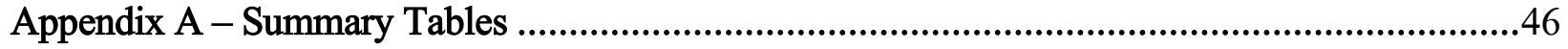

Appendix B - Classification of Food Service Types ..............................................................49

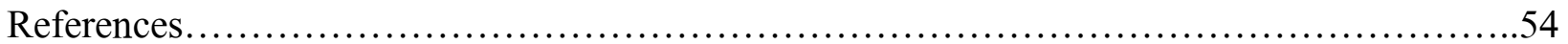




\section{List of Figures}

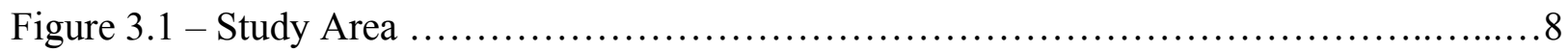

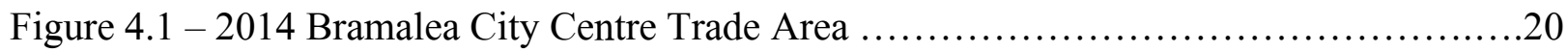

Figure 4.2 - 2019 Bramalea City Centre Trade Area............................................ 21

Figure 4.3 - 2014 CF Eaton Centre Trade Area.............................................22

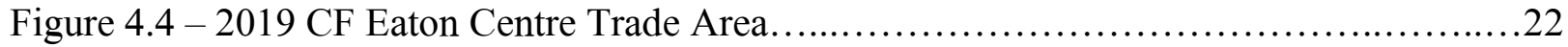

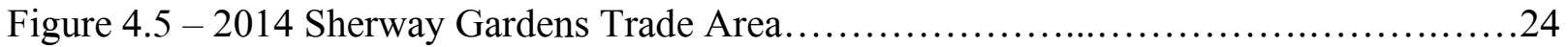

Figure 4.6 - 2019 Sherway Gardens Trade Area ..........................................24

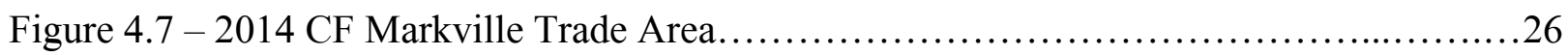

Figure 4.8 - 2019 CF Markville Trade Area.................................................... 26

Figure 4.9 - 2014 Square One Shopping Centre Trade Area.................................28

Figure 4.10 - 2019 Square One Shopping Centre Trade Area.................................28

Figure 4.11 - 2014 Erin Mills Town Centre Trade Area.........................................30

Figure 4.12 - 2019 Erin Mills Town Centre Trade Area....................................... 30

Figure 4.13 - 2014 Upper Canada Mall Trade Area..............................................32

Figure 4.14 - 2019 Upper Canada Mall Trade Area..........................................32

Figure 4.15 - 2014 CF Fairview Mall Trade Area.............................................. 34

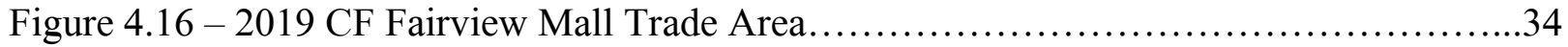

Figure 4.17 - 2014 Yorkdale Shopping Centre Trade Area...................................36

Figure 4.18 - 2019 Yorkdale Shopping Centre Trade Area......................................36

Figure 4.19 - 2014 Scarborough Town Centre Trade Area.......................................38

Figure 4.20 - 2019 Scarborough Town Centre Trade Area......................................38

Figure 4.21 - 2014 Pickering Town Centre Trade Area........................................40

Figure 4.22 - 2019 Pickering Town Centre Trade Area.....................................40 


\section{List of Tables}

Table 3.1 - Property Management Companies for Super-Regional Shopping Centres..............9

Table 3.2 - Food Service Categories.................................................... 11

Table 3.3 - Food Service Category Weightings.............................................. 13

Table 4.1 - Categorical Changes to Food Services.......................................... 15

Table 4.2 - Summary of Census Tract Changes to Shopping Centre Trade Areas.................20 


\section{List of Equations}

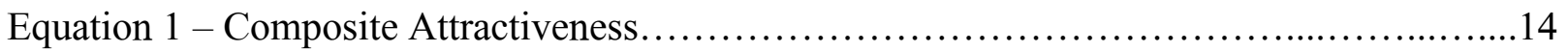

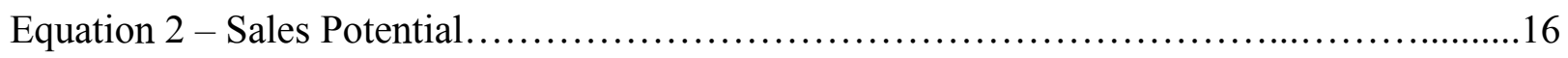




\section{Chapter 1. Introduction}

\subsection{Background \& Purpose}

Over recent years, food services (FS) have become increasingly important within the retail industry across Canada. Global real estate companies like Jones Lang LaSalle (JLL) report on FS growth and trends across the globe through their annual FS trend reports (JLL Foodservice Consulting, 2019). Industry groups such as the International Council of Shopping Centres (ICSC) have also started conducting research on how FS can thrive inside shopping centres (ICSC, 2017). Recent reports on the FS industry have highlighted the growth of the FS industry and how it may be shaped according to consumer behaviours down the line.

While traditional retailers have been moving their services online, FS remains a mostly offline industry. The main reason why it remains a relatively offline industry is that most food tends to have a short shelf life, especially food that is prepared in a shopping centre. It tends to be more perishable compared to food that's purchased at a grocery store. The consumption of food also follows specific mealtimes that define the typical day. Breakfast is usually served between the times of 8:00am - 11:00am, while lunch goes from 11:00am - 3:00pm and dinner goes from 5:00pm - 8:00pm. With some FS chains inside shopping centres opening earlier to accommodate the elderly people who tend to walk the shopping centres earlier in the morning (Duncan et al., 1995). Food courts in shopping centres tend to be busier during the Lunch and Dinner mealtimes through the week, as this is when most of the Speed Eating restaurants are busy.

FS remains a social experience (Reel, 2017), as it brings people together with some types of foods being sharable plates that can be shared within a group of people. That is one of the key reasons why FS, as an industry, has not moved entirely online. In fact, shopping centres in Canada and potentially across the world are increasingly adding more FS within the centres.

As FS spread across shopping centres away from the typical food courts, shopping centre developers like Cadillac Fairview and Oxford Properties have been experimenting with different ways to deliver food to the consumer within the shopping centres. Today, FS expands much beyond the food court; they can be found throughout the shopping centre by themselves or with 
other FS units nearby. FS can also occupy kiosks within shopping centres to attract consumers as they walk through shopping centres.

There are also other concepts that developers have been using to showcase the different types of experiences for a consumer, such as food halls, short-term and pop-up lease units within shopping centres. Food halls are a relatively new concept of FS. Food halls represent a shift in dining expectation by consumers. Part of the shift can be attributed to the 'foodie culture' as described by Cushman \& Wakefield's report on Food Halls (2016) as a new type of culture that is brought on through the rise in millennials. The rise in 'foodie culture' has affected how food halls operate. Mainly through how they source many of their ingredients, buying locally sourced ingredients has been a huge proponent in attracting millennials (Ristino, 2013).

Food halls within Canadian shopping centres are noticeably different from the typical shopping centre food courts. Many of the different types of FS that are found at food halls tend to be more premium in terms of the different types of food that is served at the food halls. Especially with the food halls that are located inside Toronto's Census Metropolitan Area (CMA) such as Toronto's first food hall, Assembly Chef's Hall that focuses on local establishments and talent (Chef Academy, 2019).

One of the most significant differences between food halls and food courts are the different types of businesses that are found within each type of food distribution concept. Some of the traditional chains that are found within food courts are not typically found inside food halls, except for a handful of chains. There are many typical chains that are commonly found in food courts which include KFC, McDonald's, and Subway.

FS are found in different format types such as food trucks, food halls, and in combination with recreational retailers such as Dave and Busters and Rec Room. It's evident that FS continues to adapt to current consumer trends and behaviours. The shopping centre industry is increasingly looking to food services to remain relevant and provide the right customer experience.

\subsection{Research \& Objectives}

This paper focuses on the recent growth of FS within eleven super-regional shopping centres across the Toronto CMA. The aim of this research is to explore the distribution of FS categories 
that are found in super-regional shopping centres within the Toronto CMA. The research analysis is based on field observations, analysis of site plans, and using trade area models. The following research questions are explored in this research:

1. What sort of changes have been occurring for Food Services in super-regional shopping centres in the Toronto Census Metropolitan Area (CMA) between 2014 - 2019?

2. Which food service categories have been seeing the most significant changes?

3. How has the change in food services in shopping centres affected their trade areas?

4. How will the changes to food services in shopping centres affect how shopping centres will operate in the near future?

\section{Chapter 2. Research Context}

Studies on food services and how they potentially affect shopping centre areas are still sparse. Recent reports have highlighted that FS has become increasingly crucial in shopping centres around the globe (JLL Foodservice Consulting, 2019). Most of the literature that has been published about shopping centres and how they change over time has been published by industry-leading organizations like the Centre for the Study of Commercial Activity (CSCA), International Council of Shopping Centres (ICSC), and the Retail Council of Canada (RCC). It covers how shopping centres have been adapting to the changes to the market, in addition to how shopping centres have been redesigned. Consumer behaviour is constantly changing, especially with the digital age where consumers have vast amounts of information on hand. All the changes that are occurring could affect how consumers are attracted to shopping centres.

\subsection{The Changing Landscape of the Traditional Shopping Centre}

Major shopping centres have gradually been changing all over the Canadian landscape, changes to the shopping centres started off occurring in some of the top-performing superregional shopping centres. As Lasaleta \& Redden (2018) note, people grow tired of seeing the same environment within any given area. Many of the food courts found in super-regional shopping centres have many of the same chains. The similarities in chains have become common in most traditional food courts, all having chains like McDonald's, KFC, and Subway. Such ubiquity pushes the consumer to overlook many of these traditional shopping centre food courts in favour of other more varied food options. 
There are many benefits to shopping online over going to the traditional shopping centre, as Gilly \& Wolfinbarger (2001) highlight there is more control and freedom for the consumer when shopping online It becomes much more difficult for traditional shopping centres to attract younger customers, as they are more likely to be purchasing the things they want through online channels (Kunbo, Jonas, Yang, \& Frank, 2019). While online shopping directly affects patrons that visit shopping centres for the sake of shopping at fashion stores. In addition to the shopping centres losing patrons to online shopping, shopping centres were stale through similar offerings and older designs. As Lasaleta \& Redden (2018) pointed out, shopping centres prior to the renovations lacked a hedonic value for many of its patrons. By 2019, most super-regional malls have gone through a major renovation or expansion. The food courts in many of these shopping centres have been redesigned as well. The Toronto Eaton Centre was one of the first superregional shopping centres to revitalize their food court, and this was completed in 2011. CF even went as far as changing the name of the food court to the Urban Eatery (Cadillac Fairview, 2019). After 2011, other property management companies followed CF's lead and changed the layout and landscape of their food courts.

Such renovations are mainly occurring to the top-performing super-regional shopping centres, where there are higher traffic and sales per sq. $\mathrm{ft}$ (Retail Council of Canada, 2018). By changing the interior landscape of many of the high-traffic super-regional shopping centres, it keeps patrons interested with many of these shopping centres (Chebat, Michon, Narjes, \& Oliveira, 2014). One of the main challenges for any shopping centre is to constantly keep patrons interested in what is happening within the shopping centre, while renovations and expansion will draw in patrons immediately after they are completed. It is often the experiences that many of the patrons will have that will keep them coming back.

Growth in FS retailers is, therefore, increasing in shopping centres across Canada, especially as consumers visiting shopping centres are becoming interested in non-retail-based activities within many of these shopping centres (International Council of Shopping Centres, 2016).

\subsection{The Digital Consumer}

Although the change in consumer behaviour is not just limited to the retail environment, it occurs in food service industries as well. New technologies related to FS have emerged in the 
Toronto area over the past couple of years. As JLL has pointed out, the trends in the FS market are creating an environment where access to food is readily available no matter where the consumer is (JLL Foodservice Consulting, 2019). Mobile apps such as Ritual have made it easier for consumers to pre-order from a selection of restaurants; users would receive a notification to tell them to start walking to the restaurant. This allows the consumer to cut the wait time for a meal to almost zero. Mobile apps like UberEATS, Foodora, and DoorDash have made it easier for consumers to enjoy restaurant meals in the comfort of their homes. Younger consumers with access to technology are more likely to adopt online retailing behaviours (Doub et al., 2015; Kunbo et al., 2019). New technologies like Foodora and Ritual are available in the urban parts of the Toronto CMA. Berry, Seiders, and Grewal (2002) have discussed the importance of convenience, especially for younger consumers.

Digital marketing has changed the ways in which FS have been viewed by consumers. Through Instagram, users can post photos of anything they want. Food-related posts can be used to gather the attention of their followers, which in turn generates interest for that product. The idea of marketing products through social-media has already affected how consumers decide to consume food (Cyr et al., 2018) as they are swayed by what is shown on the Instagram feed. How all this affects shopping is that FS across the board are increasingly trying to create extremely photogenic meals for people to post photos about. It has become a trend for FS to create aesthetically pleasing items in order to allow consumers to take photos of the item that they are purchasing. This allows customers and their followers (i.e., potential customers) to food experiences. Positive experiences are what drives customer satisfaction (Pine \& Johns, 2002) and customers are likely to return because of it.

As FS has been growing in shopping centres, so have the types of food that are being sold. Current trends are pointing towards consumers who are health conscious in what they are eating (Cyr, et al., 2018). These health-conscious consumers are more likely to purchase organic foods due to their perceived health and environmental benefits (Gracia \& Magistris, 2007). Local food has also been on the rise, partly due to the increase in the number of farmer's market, as well as many locally-sourced restaurants around the Toronto CMA. Like organic foods, there is a premium price attached to buying healthy locally-sourced foods (Hempel \& Hamm, 2016). There has been a rise to alternative sources of meat, with products such as Beyond Meat leading the 
growth into alternative sources. With mainstream FS firms such as Tim Horton's and A\&W embracing Beyond Meat in their menu (Harris, 2019). Fast-casual chains have seen significant growth in recent years, although it is a concept that has existed for decades. It is a category of FS that has become popular in and out of shopping centres. Fast-casual restaurants have the perception of being higher quality and healthier than their fast-food counterparts. (Mathur \& Gupta, 2019). This also speaks towards the interior of many fast-casual chains like Panera Bread and Chipotle, that often feel more inviting and comforting compared to a McDonald's or Burger King. Growth in fast-casual restaurants can be attributed to changing consumer behaviour.

\subsection{Trade Areas}

The trade area is a term that describes where a store location receives most of its customer base. Trade areas can differ in size and population within it; they follow a set of parameters that are usually set by the users that are creating the trade area (i.e., size of the business, average distance consumers are willing to travel for the product, and number of retailers within a shopping centre). Hernandez et al. (2004) describe three types of trade areas; deterministic, probabilistic, and rule-based trade areas.

With the three types of trade areas, the one that is being focused on in this research is the probabilistic trade area. This type of trade area is more complicated than that of a deterministic type but less complex than a rule-based trade area. The probabilistic trade area is more complicated in the sense that it brings in the Reilly's Gravity model into consideration when determining trade areas (Reilly, 1929). The gravity model explains how larger retailers are able to attract more consumers. The probabilistic model also incorporates the concept of distance decay, which Tobler (1970) describes as 'everything is related to everything else, but near things are more related than distant things'. The two main determinants of the size of probabilistic trade areas are the size of the retailer and the distance the targeted customer is away from the retailer. The further the targeted customer is from the retailer the less likely they are to go, the closer they are, the more likely they are to go.

Trade areas that use gravity as a factor in determining the size of the trade area can be simplified using the concepts of primary, secondary and tertiary trade areas. The primary trade area for a shopping centre is the defined boundary where that centre receives $60 \%$ and above the patronage of the geographic area. The secondary trade area is where a shopping centre receives 
$40 \%-60 \%$ of the patronage while the tertiary trade area is any geographic unit where the shopping centre receives less than $40 \%$ of the market population.

The Huff model has become a staple method for creating complex probabilistic trade areas for multiple retailers in a single market. The Huff model is one of the advanced versions of the probabilistic trade area types, as it incorporates the more than just distance and size into the creation of a trade area (Huff, 1964). How the model differs is that it incorporates a composite attractiveness variable. The model also differs by being able to incorporate other competing sites. Trade areas are defined within the Huff model through the consideration of the sales potential within each geographical unit in the trade area, along with a probability that is each geographic unit in the trade area has with spending money at the retail location (Diaz \& Acuna, 2015).

Huff models ranging from site selection of supermarkets, hospitals through park and ride locations (Diaz el al, 2015; Lin, et al., 2016). In this research, a Huff model is created that factors in the attractiveness of FS retailers and as well as non-FS retailers in each of the 11 superregional shopping centres within the Toronto CMA. The weighting scheme between the two types of attractiveness is split to highlight the changing consumer behaviour on shopping centres, with $60 \%$ of the weighting for non-FS retailers and $40 \%$ being for FS retailers in SCs. The weighting scheme is reflective of the growing FS trends as well as the acknowledgement that non-FS retailers still attract most of the shopping centre's patrons (JLL Foodservice Consulting, 2019; ICSC, 2017). The change in leased sq. $\mathrm{ft}$ is used as a metric in this study to measure the changes in occupancy of FS and non-FS type units.

\section{Chapter 3. Research Method \& Methodology}

\subsection{Study Area}

This research focuses on Toronto (see Figure 3.1), Canada's largest CMA with a resident population of 5.9 million in 2016 (Statistiics Canada, 2017). According to the Retail Council of Canada (RCC), some of the country's most top-performing shopping centres can be found in the Toronto area (Retail Council of Canada, 2018).

Different types of FS concepts have been opening within shopping centres have seen food halls and pop-up retailers open within them. There have also been food halls that have been opening throughout the city, including, Assembly Chefs Hall in the financial district of Toronto 
and Annex Food Hall just west of Bloor Street \& Spadina Avenue in Toronto. There are also other food halls that have opened and are connected to higher-end grocery chains. Currently, there are two grocery chains that operate food halls within their property; namely McEwan's \& Pusateri's.

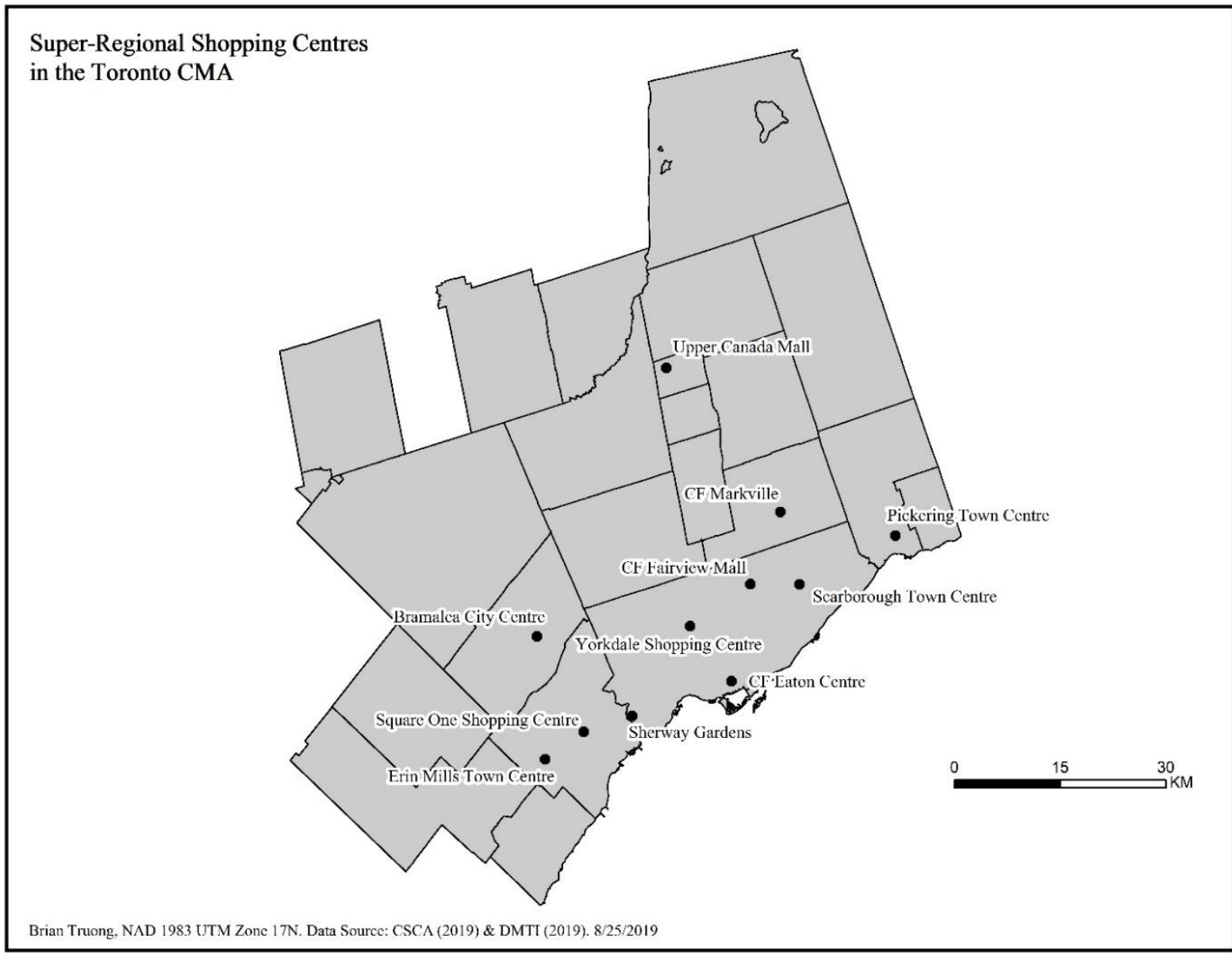

Figure 3.1 Toronto CMA with the location of 11 super-regional shopping centres.

\subsection{Study Year}

Changes in FS real estate in shopping centres occur every year, in order to test the research question of identifying the change in FS real estate, the current year must be compared with a previous year. In this study, super-regional shopping centres are compared between 2014 data and 2019 data. 


\subsection{Data Sources}

Since this research relies heavily on retail data from multiple years, it draws most of the data from the CSCA. The research gathers some tenant data from their Shopping Centre Database (SCD), and it also uses the Major Food Service (MFS) database's FS categories to classify the FS retailers and uses the database as a guide when classifying FS retailers. Most of the tenant data in this research were gathered from site plans of the super-regional shopping centres in 2014; these site plans were used to create a full dataset of each tenant in each superregional shopping centre in 2014 and 2019.

The reason why only some tenant data are used in this research is that this research relies heavily on site plan information. The CSCA has archived site plans of all major shopping centres since 2014. The quality of site plan information has dramatically improved over the past five years, though it is still largely dependent on which property management company provided the data. Between the 11 super-regional shopping centres in Toronto, there are several property management companies that are responsible or releasing annual site plans for these properties. Table 3.1 identifies which property management company was responsible for each property in 2014 - 2019. For the three super-regional shopping centres that are being used for the case study in this research, they are all managed by Oxford Properties.

Table 3.1 - Property Management Companies for Super-Regional Shopping Centres

\begin{tabular}{|c|c|c|}
\hline \multirow{2}{*}{ Shopping Centre Name } & \multicolumn{2}{|c|}{ Property Management Company } \\
\cline { 2 - 3 } & Morguard & Morguard \\
\hline Bramalea City Centre & 20 Vic Management & Cushman \& Wakefield \\
\hline Erin Mills Town Centre & Cadillac Fairview & $\begin{array}{c}\text { Cadillac Fairview/Ivanhoe } \\
\text { Cambridge }\end{array}$ \\
\hline Fairview Mall & Cadillac Fairview & Cadillac Fairview \\
\hline Markville Shopping Centre & 20 Vic Management & Cushman \& Wakefield \\
\hline Pickering Town Centre & Oxford Properties & Oxford Properties \\
\hline $\begin{array}{c}\text { Scarborough Town Centre } \\
\text { (STC) }\end{array}$ & Cadillac Fairview & Cadillac Fairview \\
\hline Sherway Gardens & Oxford Properties & Oxford Properties \\
\hline Square One Shopping Centre & Cadillac Fairview & Cadillac Fairview \\
\hline The Toronto Eaton Centre & Oxford Properties & Oxford Properties \\
\hline Upper Canada Mall & Oxford Properties & Oxford Properties \\
\hline Yorkdale Shopping Centre & &
\end{tabular}




\subsubsection{Data Collection}

Tenant information within the super-regional shopping centres for 2014 and 2019 was compiled for the purpose of the research. The data were collected individually by going through each of the site plans and entering each store name of each tenant and the size of the unit that they occupy. The pad units of shopping centres were also added to the dataset for both years. All sq. ft information on shopping centres and their surrounding pads were collected.

For the 2014 site plans, most of the super-regional shopping centres had unit sizes except for Scarborough Town Centre and Upper Canada Mall, both being from Oxford Properties (Table 3.3). Sizing for the shopping centres that belonged to 20 Vic Management were roughly estimated sizes, although it was not explicitly stated on the site plan, the sizes themselves were rounded to the nearest hundred (20 Vic Retail, 2014). Lastly, throughout 2014, Sherway Gardens was undergoing a renovation to modernize its retail space. Due to the ongoing renovations in 2014, Sherway Gardens had less leasable space which resulted in an overall measurement of the retail size. Especially when comparing with the 2019 sq. ft sizes of the mall. As for the 2019 shopping centre dataset, the collection method was conducted in the same manner as the 2014 dataset. Properties that were managed by Cushman \& Wakefield, which are Erin Mills Town Centre and Pickering Town Centre did not have any sizing information available on the site plans.

For the malls that did not have any unit sizes, the sizes in the CSCA's SCD were used as a substitute. For the 2014 missing shopping centre sizes that were missing, the 2013 SCD release was used, and for the 2019 missing shopping centre sizes the 2018 SCD release. However, with the CSCA's SCD database, not every retailer is collected, only Major Retail Chains (MRC) are collected for the database. With the shopping tenants that were not in the SCD, an estimated size was given based on their approximate location within the shopping centre. The stores that were missing from the CSCA's database were determined by cross-referencing the CSCA's store name within each shopping centre with each of the shopping centre's site plans for the target year. Stores that were found to be non-FS units in shopping centres were given one size, which would be the average of unit sizes for that shopping centre. If a food court unit was missing, then it was estimated based on the average unit food court sizes for that shopping centre. Stores that were noted as kiosks in site plans were given a size of $200 \mathrm{sq}$. $\mathrm{ft}$, across all missing shopping 
centres. As for stores that were in pad locations, Google Maps measurement tool was used to determine a rough estimate of the size of the pad.

Statistics Canada is the other secondary data source, which was gathered through Simply Analytics, which is a platform that provides data to education institutions. Simply Analytics also draws some of their more specialized data from Environics Analytics which is a Canadian marketing company that manages and creates their own datasets through using surveying and data mining techniques (Environics Analytics, 2019). Income-related variables such as average household income and house expenditures variables (i.e. food expenditure) were downloaded. For 2014 average household income, DemoStats 2014 was used to gather the average household income of each CT in the CMA. The food expenditure dataset was part of Environics' HouseholdSpend dataset, both the 2015 and 2019 release of the dataset was used in this research. The specific expenditure data that is used in the analysis is 'food expenditure on restaurant,' 'Personal Care,' 'Clothing,' 'Games of Change - Government-Run', and 'Recreation - Home Entertainment Equipment.' Street-network data from DMTI Spatial was used to provide Manhattan-style distance measurements for the Huff Model.

\subsection{Methodology}

The tenant data were separated into FS retailers and non-FS retailers. This was done in order to identify if there have been noticeable changes to the FS sq. $\mathrm{ft}$ in the shopping centres between 2014 and 2019. A column was created alongside the Tenant Name, an ID of '1' was given to tenants that were identified as FS, while an ID of '2' was given to non-FS tenants, and lastly, an ID of ' 3 ' was given to vacant units. Offices and pad locations were ignored in this process, in order to ensure that the pure retail sq. $\mathrm{ft}$ was calculated for each shopping centre. A FS Category ID was also assigned to each tenant that had a FS ID, each of the FS Category IDs along with their descriptions are shown in Table 3.2. These FS Category IDs are FS categories that are used in the CSCA's MFS database. This was done to ensure that the research aligned with industry standards. Note, FS ID $6 \& 7$ were not identified in any of the super-regional shopping centre units in either 2014 or 2019.

Table 3.2 - Food Service Categories

\begin{tabular}{|c|c|c|c|}
\hline FS ID & $\begin{array}{c}\text { Food Service } \\
\text { Category }\end{array}$ & Examples & Description \\
\hline
\end{tabular}




\begin{tabular}{|c|l|l|l|}
\hline $\mathbf{1}$ & Impulse & $\begin{array}{l}\text { Jamba Juice, Cinnabon, } \\
\text { Chatime }\end{array}$ & $\begin{array}{l}\text { "Treat" purchases, often handheld. } \\
\text { Consumption on the Move. }\end{array}$ \\
\hline $\mathbf{2}$ & Refuel and Relax & Starbucks, Tim Hortons & $\begin{array}{l}\text { The focus for user and unit is the } \\
\text { beverage. }\end{array}$ \\
\hline $\mathbf{3}$ & Speed Eating & $\begin{array}{l}\text { McDonald's, Wendy's, } \\
\text { KFC }\end{array}$ & $\begin{array}{l}\text { Food that is purchased \& consumed } \\
\text { quickly }\end{array}$ \\
\hline $\mathbf{4}$ & Fast-Casual & $\begin{array}{l}\text { Freshii, Panera Bread, } \\
\text { Chipotle }\end{array}$ & $\begin{array}{l}\text { Food that is made or finished to } \\
\text { order. Guests are involved in the } \\
\text { service process. }\end{array}$ \\
\hline $\mathbf{5}$ & Casual Dining & $\begin{array}{l}\text { Jack Astor's, Mandarin, } \\
\text { East Side Mario }\end{array}$ & $\begin{array}{l}\text { The broadest category, with infinite } \\
\text { cuisines. Table service. The } \\
\text { environment is just as important as } \\
\text { the food. }\end{array}$ \\
\hline $\mathbf{6}$ & Finer Dining & Morton's Steakhouse & $\begin{array}{l}\text { The highest level of food service. } \\
\text { Sophisticated experience. High price } \\
\text { and longer dwell times. Dress code. }\end{array}$ \\
\hline $\mathbf{7}$ & Social Drinking & $\begin{array}{l}\text { Bier Market, The Three } \\
\text { Brewers. }\end{array}$ & $\begin{array}{l}\text { Alcohol-led units, but not just about } \\
\text { alcohol. Food is just as important, } \\
\text { Places of social interaction. }\end{array}$ \\
\hline $\mathbf{8}$ & Gourmet Food & $\begin{array}{l}\text { Purdy's Chocolate, } \\
\text { Sugarfina, Squish }\end{array}$ & $\begin{array}{l}\text { Mainly retail food to buy and take } \\
\text { away Can also have an element to } \\
\text { eat-in. }\end{array}$ \\
\hline $\mathbf{9}$ & Premium Casual & $\begin{array}{l}\text { The Keg, JOEY, Cactus } \\
\text { Club }\end{array}$ & $\begin{array}{l}\text { Contemporary full-service dining } \\
\text { experience. Casual dining with } \\
\text { upscale menu and beverage } \\
\text { offerings. }\end{array}$ \\
\hline
\end{tabular}

Source: CSCA Major Food Service Database, 2019

\subsection{Exploratory Huff Model}

\subsubsection{Attractiveness Calculations}

A Huff models was created that combined the different variables of attractiveness in a given shopping centre. The attractiveness variables of the Huff models split between FS retailers and non-FS retailers; the non-FS retailers are composed of any that has a FSID of ' 2 ', while FS retailers have a FSID of ' 1 '. The sq. $\mathrm{ft}$ of the vacant units will largely be ignored in the determination of the composite attractiveness variable. This is because the composite attractiveness variable is being created based on a consumer's standpoint of the shopping centre. Meaning that consumers would be more concerned with the different types of retailers and FS 
that are available at each shopping centre rather than the number of vacant units or how much vacant space a shopping centre has.

Equation 1 - Composite Attractiveness Equation

$$
\mathrm{A}=\Sigma\left(\mathrm{V}_{\mathrm{x}} * \mathrm{~W}_{\mathrm{x}}\right)
$$

$\mathrm{V}_{\mathrm{x}}$ represents each variable that will be considered as an attractiveness variable. $\mathrm{W}_{\mathrm{x}}$ represents the assigned weight for the corresponding attractiveness variable.

The composite attractiveness variable was created with the combination of both the FS spaces and non-FS spaces (Figure 3.2). Shopping centres largely remain a space for consumers to shop for non-FS merchandise, although FS is growing within shopping centres it is still overshadowed by non-FS retailers. Because of that, non-FS retailers account for $60 \%$ of the composite attractiveness, while FS retailers account for $40 \%$ of the attractiveness. The weighting of FS retailers is further split through the different types of categories of FS. The exact weightings of each of the attractive for each category are shown in Table 3.3. The weighting scheme of FS categories follows the concept of high and low order goods (Holton, 1958). The weights, while subjective, place emphasis on the different types of dining that would typically be available at a shopping centre.

Table 3.3 - FS Category Weightings

\begin{tabular}{|r|c|}
\hline \multicolumn{1}{l}{$\begin{array}{l}\text { Food Service } \\
\text { Category }\end{array}$} & Weighting (Out of 40\%) \\
\hline Impulse & 4 \\
\hline Refuel and Relax & 5 \\
\hline Speed Eating & 3 \\
\hline Fast-Casual & 6 \\
\hline Casual Dining & 13 \\
\hline Finer Dining & N/A* \\
\hline Social Drinking & N/A* \\
\hline Gourmet Food & 4 \\
\hline Premium Casual & 10 \\
\hline
\end{tabular}

* Finer Dining and Social Drinking were omitted as they were not present in the superregional centres studied in either 2014 or 2019 
For the data to be comparable with each of the shopping centres, the data for each year were re-scaled. The re-scaling method takes the smallest size of each FS category and uses that as the denominator when it is divided by the sizes from other shopping centres that share FS category. For example, if a Toronto Eaton Centre has a Fast-Casual total size of 20,345 sq. $\mathrm{ft}$ and Yorkdale Shopping Centre has a Fast-Casual total size of 34,277 sq. $\mathrm{ft}$ then after re-scaling the data the Toronto Eaton Centre would have a value of 1 for the Fast-Casual FS category while Yorkdale Shopping Centre would have a measurement of 1.68. This would indicate that in terms of Fast-Casual cuisines between the Toronto Eaton Centre and Yorkdale Shopping Centre, it would be Yorkdale Shopping Centre that would have a higher attractiveness for fast-casual dining. The re-scaling of data will be applied across each of the variables that are used in the attractive equation, which is shown below

\subsubsection{Origin Locations \& Sales Potential}

The Huff model uses the locations of the shopping centres in the study area as the origin locations. These potential market areas are mainly derived from the chosen distance friction coefficient; in this model, the coefficient is 2 . A lower distance friction coefficient indicates that consumers are more willing to travel further for the establishment (ESRI, n.d.), while a higher coefficient represents that people are willing to travel less. An example of a low distance friction coefficient retailer is a furniture store like Ikea, which is not readily available in most parts of the CMA. While a high distance coefficient retailer is a convenience store. The distance friction coefficient mimics the attractiveness of high and low order retailers (Holton, 1958).

Equation 2 - Sales Potential

$$
\mathrm{SP}=\left(\mathrm{HH}_{*} * \operatorname{Avg}_{\mathrm{Hн}} * \% \mathrm{HH}_{\mathrm{S}} * \mathrm{H}_{\%}\right)
$$

$\mathrm{HH}_{*}$ represents the number of households within the $\mathrm{CT}$, Avg $\mathrm{gнн}_{\text {ни }}$ represents the Average Household Income for the $\mathrm{CT}, \mathrm{HH}_{\mathrm{s}}$ represents the percentage of expenditure that a household is likely to spend at the shopping centre, and lastly $\mathrm{H}_{\%}$ ) represents the probability that consumers from that $\mathrm{CT}$ will visit the shopping centre this value is determined from running the Huff model.

The Huff model requires the sales potential of each CT in each of the study years. Sales potential data was estimated through HouseholdSpend data. The equation for sales potential is shown in Figure 3.3; two sales potential equations were created, one for each of the study years. 
The appropriate data were collected for each of the years under the same HouseholdSpend dataset by Environics Analytics.

\section{Chapter 4. Analysis}

\subsection{Changes in Food Services across Super-Regional Shopping Centres}

Throughout the study period, there have been many changes to the FS industry both in and outside of shopping centres, some of the most significant changes in the FS industry have made their way into shopping centres, such as food halls (Cushman \& Wakefield, 2019). Two food halls have been built inside super-regional shopping centres across the CMA. Both shopping centres have re-purposed a portion of their old Target location that was left vacant by Target's sudden departure from the Canadian market.

The first food hall that opened was in Upper Canada Mall, which is called Market \& Co. The focus of Market \& Co is to allow patrons of Upper Canada Mall to experience an elevated FS experience. This is achieved through the introduction of full-service restaurants as well as a mix of Impulse, Fast-Casual, and Gourmet FS within the food hall (Patterson, 2018). The second food hall is found in another Oxford Properties shopping centre, Square One Shopping Centre. The food hall in Square One named, Food District only occupies a portion of the old Target unit, splitting it with other retailers such as Indigo, Rec Room, and Uniqlo. Rec Room being a mix of FS and recreational experiences works well with the nearby food hall concept. Like its counterpart, the Food District contains a mix of FS categories within it, ranging from Impulse to Fast-Casual to Gourmet FS even going as far as sharing similar retailers within the food hall (Oxford Properties, 2019). It is not just food halls that are bringing different types of FS experiences into the shopping centre. One of the other most notable changes is that patrons can find FS interspersed throughout the shopping centre. There has been a rise in FS that can be found throughout the mall, mainly Impulse retailers. One of the most notable types of Impulse FS is the rise of Bubble Tea chains within Shopping centres, such as Real Fruit Bubble Tea store. While chains like Real Fruit Bubble Tea have their own storefront in shopping centres, some of the existing Impulse FS have adapted and changed their menu to start offering Bubble Tea products. Most notably Freshly Squeezed and Yogen Fruz has begun selling Bubble Tea products to follow the trend. Casual Dining units have also started to appear inside shopping 
centres, while some can be found in food halls, restaurants like Jamie Oliver's Italian Kitchen can be found inside the newer portions of shopping centres (Oxford Properties, 2019).

\subsection{Trends in Shopping Centre Food Services}

Table 4.1 highlights changes in FS categories across all the super-regional shopping centres. Note that some entries in the table have growth without a percentage increase due to zero values in 2014. The biggest growth in FS is in the Impulse and Gourmet Food Category. The triple-digit percentage increase in these categories highlights the growing popularity of many of these types of FS categories inside shopping centres. However, the rise in Impulse and Gourmet Food moves beyond Food Halls as shopping centres have started to incorporate these FS categories throughout the shopping centre. The rise in Impulse FS is due to the growth in either 'healthy' or 'indulgence' FS chains.

Table 4.1 - Categorical Changes to Food Services

\begin{tabular}{|r|c|c|c|c|c|c|c|}
\hline $\begin{array}{c}\text { Super-Regional } \\
\text { Shopping } \\
\text { Centre }\end{array}$ & $\begin{array}{c}\text { Impulse } \\
(1)\end{array}$ & $\begin{array}{c}\text { Refuel } \\
\text { and } \\
\text { Relax } \\
(2)\end{array}$ & $\begin{array}{c}\text { Speed } \\
\text { Eating } \\
(3)\end{array}$ & $\begin{array}{c}\text { Fast- } \\
\text { Casual } \\
(4)\end{array}$ & $\begin{array}{c}\text { Casual } \\
\text { Dining } \\
(5)\end{array}$ & $\begin{array}{c}\text { Gourmet } \\
\text { Food } \\
(8)\end{array}$ & $\begin{array}{c}\text { Premium } \\
\text { Casual } \\
(9)\end{array}$ \\
\hline $\begin{array}{r}\text { Bramalea City } \\
\text { Centre }\end{array}$ & $219 \%$ & $32 \%$ & $17 \%$ & $\mathrm{G}^{*}$ & $\mathrm{G}^{*}$ & $2 \%$ & $0 \%$ \\
\hline $\begin{array}{r}\text { CF Eaton } \\
\text { Centre }\end{array}$ & $64 \%$ & $4 \%$ & $16 \%$ & $0 \%$ & $0 \%$ & $247 \%$ & $-34 \%$ \\
\hline $\begin{array}{r}\text { CF Markville } \\
\text { Erin Mills }\end{array}$ & $-29 \%$ & $1 \%$ & $22 \%$ & $\mathrm{G}^{*}$ & $-83 \%$ & $-25 \%$ & $0 \%$ \\
\hline $\begin{array}{r}\text { Town Centre } \\
\text { Fairview Mall }\end{array}$ & $79 \%$ & $17 \%$ & $-13 \%$ & $\mathrm{G}^{*}$ & $-65 \%$ & $6 \%$ & $-100 \%$ \\
\hline $\begin{array}{r}\text { Pickering } \\
\text { Town Centre }\end{array}$ & $42 \%$ & $-31 \%$ & $-2 \%$ & $0 \%$ & $257 \%$ & $12 \%$ & $\mathrm{G}^{*}$ \\
\hline $\begin{array}{r}\text { Scarborough } \\
\text { Town Centre }\end{array}$ & $64 \%$ & $47 \%$ & $17 \%$ & $\mathrm{G}^{*}$ & $-38 \%$ & $-9 \%$ & $10 \%$ \\
\hline $\begin{array}{r}\text { Sherway } \\
\text { Gardens }\end{array}$ & $81 \%$ & $-4 \%$ & $-25 \%$ & $192 \%$ & $26 \%$ & $73 \%$ & $\mathrm{G}^{*}$ \\
\hline $\begin{array}{r}\text { Square One } \\
\text { Shopping } \\
\text { Centre }\end{array}$ & $106 \%$ & $45 \%$ & $-16 \%$ & $5 \%$ & $161 \%$ & $240 \%$ & $-37 \%$ \\
\hline $\begin{array}{r}\text { Upper Canada } \\
\text { Mall }\end{array}$ & $25 \%$ & $77 \%$ & $16 \%$ & $897 \%$ & $-7 \%$ & $325 \%$ & $\mathrm{G}^{*}$ \\
\hline $\begin{array}{r}\text { Yorkdale } \\
\text { Shopping } \\
\text { Centre }\end{array}$ & $169 \%$ & $231 \%$ & $-24 \%$ & $\mathrm{G}^{*}$ & $-20 \%$ & $560 \%$ & $238 \%$ \\
\hline
\end{tabular}

Growth*: Indicates growth from 0 sq. $\mathrm{ft}$. 
Smoothie chains like Booster Juice and Jugo Juice, Cold Press Juice which has seen a rise in popularity due to its perceived nutritional benefits by consumers are the 'healthier' Impulse FS in shopping centres. While chains like Real Fruit Bubble Tea, Auntie Anne's, and Sweet Jesus are aiming to indulge patrons with sweet and tasty products. Auntie Anne's has grown in many of the super-regional FS across the CMA, mainly because of its reliance on scent marketing, that is a type of marketing that markets a product in this case, pretzels through smell (Grybś, 2018), patrons would smell delicious baked dough as they walk by the retail unit and become interested in the product while Sweet Jesus focuses on the visual appeal of their products. It pushes patrons to show-off their outrageous ice cream creations on social media (Cyr et al., 2018), which in turn gives the individual gratification from their followers.

The Refuel and Relax FS categories see smaller percentage growth than the Impulse category mainly because Refuel and Relax already has an established presence inside superregional shopping centres, with leading players like Tim Hortons, Starbucks and Timothy's. The slight rise in Refuel and Relax is due to new entrants to the shopping centre. New FS retailers like Danish Pastry House have been increasingly expanding in shopping centres through their two FS formats; Brod which markets themselves as a Danish bakery and coffee shop (Brod, 2019), and the other being the well-known Danish Pastry Shop.

Tea focused brands have experienced ups and down; Teavana which was owned by Starbucks closed all of their stores in 2018 (Taylor, 2018) other chains like David's Tea remain open in all shopping centres. The addition of Food Halls have brought some Refuel and Refresh businesses; Food District brought in Hale Coffee Roasters, a Toronto based roastery. While Yorkdale attracts retailers that have a premium international reputation, for example, Laduree, a French Patisserie opened their first Canadian location in Yorkdale Shopping Centre. While this category is not seeing significant changes in shopping centres, it is not declining.

With the rise of other FS categories in shopping centres, Speed Eating has remained relatively stable in shopping centres. Speed Eating retailers are still primarily located in Food Courts. The benefit of shopping centres having Speed Eating retailers in their Food Courts is that some Speed Eating Retailers offer specific meals for certain times of the day such as Breakfast, Lunch and Dinner (ICSC, 2017). That versatility allows Speed Eating to remain prominent in 
shopping centres as opposed to some of their growing categories like Fast-Casual and Premium Casual FS which may not offer a full day meal option.

The three shopping centres that have experienced a decrease in Speed Eating are Sherway Gardens, Square One Shopping Centre, and Yorkdale Mall. These three centres have all undergone major food court renovations throughout the study period, along with Square One introducing their food hall concept. Through the renovations these shopping centres have decreased their offerings of Speed Eating retailers and have all expanded their offerings of fastCasual FS. These shopping centres are following the consumer behavioural trend of eating healthier (Mathur et al, 2019) by introducing more Fast-Casual retail options. As many Speed Eating establishments have been associated with unhealthy meals such as McDonald's (Robinson et al, 2016). Also, Fast-Casual establishment has been associated with better quality food and ingredients that are available for consumers (Mathur et al, 2019).

There has been an increase in the number of Fast-Casual chains in shopping centres, in 2014 the most common Fast-Casual establishments was Cultures, which is a typical fast-casual restaurant that allows patrons to identify which type of ingredients they want in to consume, in a bowl or salad format. One of the biggest reasons why fast-casual establishments have become popular with mainstream consumers is that they encourage customization of set menu items. This allows consumers to have a perceived sense of uniqueness when ordering their meal (The Economist, 2015), which enhances their experience dining at that establishment.

Casual Dining as a FS is typically for families looking to eat out. Casual Dining restaurants were typically located in the shopping centre pad where there is enough space for these larger restaurant establishments. In 2019, several shopping centres have seen casual dining establishments within the shopping centre itself, such as Jamie Oliver's Italian Kitchen, Reds, and Cheesecake Factory in Yorkdale. The substantial increase of Casual Dining in Square One (Table 4.1) is due to shopping centres adding plenty of Casual Dining FS near the entrances of the shopping centre. Square One Shopping Centre has introduced unique retailers like Santosei Ramen, Reds, and Jamie Oliver's Italian Kitchen along with the food hall which brought in La Carnita. Pickering Town Centre experienced the most substantial growth in Casual Dining. With Casual dining establishments, only a handful of conglomerates own most of the casual dining establishments. Recipe Unlimited and Sir Corp own a large number of restaurants in shopping 
centre pad locations, while Recipe Unlimited also focuses on Speed Eating FS in shopping centres.

Gourmet Foods has seen the largest percent growth out of the 7 FS categories that are in shopping centres. Part of this growth can be attributed to a growing preference more high-quality goods. These goods are often ethnically sourced, for example Seed to Sausage in both Square One Shopping Centre and Upper Canada Mall offer butcher cut meats and other products at a premium price point (Porral et al, 2016). While the initial price point of many of Gourmet Food establishments may ward off some consumers, most consumers tend to associate higher prices with higher quality. The way the food products are marketed reflect that perception of quality, which in turns drives consumer loyalty (Porral et al, 2016; Sosianika et al, 2019).

The rise of Gourmet Food is occurring across most of the shopping centres. The older Gourmet Food establishments are mainly chocolatiers that have been in shopping centres for quite some time; these establishments include Godiva, Lindt, Purdy's Chocolatier, and Rocky Mountain Chocolate Factory. Many of these FS chains have a loyal customer base, especially Lindt which is well known for giving free samples at their stores. All these establishments are chocolate-based Gourmet Foods that use similar concepts to Impulse FS which markets products to human senses (Grybś, 2018), for example the visual appeal of the chocolate fountains that are in window displays. Newer Gourmet Food establishments have diversified from chocolate offerings to offer gourmet sweets such as Squish and Sugarfina. Both retailers package their products in a manner that is aesthetically pleasing to the consumers, which entice them to purchase the product (Калініна et al, 2016; Palmieri, 2018).

Food halls have also brought in Gourmet Food establishments; these retailers differ from the ones that are found throughout shopping centres. What makes Gourmet Foods establishments different in the Food Halls is that they cover a variety of food products, such as Seed to Sausage, Kingston Olive Oil Co., Secret Lands Farm, Junction Fromagerie, Newmarket Olive Oil Co., and Our Farm Organic Bakery. Like all Gourmet Food these retailers offer a higher price point product while relying on brand loyalty for growth.

Premium Casual restaurants have seen some growth in super-regional shopping centres. This category caters to upscale dining as opposed to mainstream family dining. Table 4.1 
highlights overall growth in Premium Casual, with most of that growth occurring in shopping centres where there were no Premium Casual establishment in 2014.

The one shopping centre that stands apart from growth in Premium Casual establishments is Yorkdale Shopping Centre. Yorkdale already has a reputation for being a high-end shopping centre, one that is responsible for introducing many international retailers to the Canadian Market. The reputation of being a high-end shopping centre extends to the type of dining experiences that patrons can experience (and increasingly expect) while shopping at Yorkdale. Although Yorkdale does not have a high number of Premium Casual dining options, the ones that are there are relatively unique. Joey's is the only FS chain out the three Premium Casual dining options at Yorkdale. The others are Restoration Hardware Café, and Tora, both establishments are unique and break the norm of premium casual dining. First, Restoration Hardware Café is a premium casual dining experience that is within a high-end furniture store. Tora is a part of Aburi Restaurant's sushi empire in Canada, (Aburi Restaurant's, 2019). What makes Tora unique is that they serve their sushi on a conveyor belt while the quality of the product follows Aburi Restaurant's standards. These two Premium Casual restaurants move enhance the shopping experience for consumers reinforcing Yorkdale Shopping Centre's reputation as the best performing shopping centre in North America (Retail Council of Canada, 2018).

\subsection{The Impacts of Food Services on Shopping Centre Trade Areas}

\subsubsection{Bramalea City Centre}

Located in Brampton, it is the only super-regional shopping centre for that municipality (Morguard, 2019), it has not seen a lot of changes over the study period. The biggest thing that occurred was Target vacating their unit. Which has since been partially filled by Saks Off $5^{\text {th }}$ (Morguard, 2019). Bramalea City Centre's primary trade area in 2014 (shown in Figure 4.1) shows a relative tight trade area that is mainly defined by boundaries of the City of Brampton. Central Brampton is mainly within its Primary area. Looking at Bramalea City Centre's trade area in 2019 (shown in Figure 4.2) shows a more significant primary trade, along with a secondary trade area that extends up to the town of Caledon. Part of the reason for the growth in trade area could be attributed to the growth in FS that can be found in Bramalea City Centre. 
According to Table 4.1 it shows that Bramalea City Centre experienced an overall growth in most types of FS categories, with an overall increase of FS by $42 \%$ (Table 4.2).

Table 4.2 - Summary of Census Tract Changes to Shopping Centre Trade Areas

\begin{tabular}{|r|c|c|c|c|c|c|}
\hline & \multicolumn{2}{|c|}{2014} & \multicolumn{2}{c|}{2019} & \multicolumn{2}{c|}{$\%$ Change } \\
\hline Shopping Centre & Primary & Secondary & Primary & Secondary & Primary & Secondary \\
\hline Bramalea City Centre & 33 & 43 & 53 & 40 & $60.6 \%$ & $-7.0 \%$ \\
\hline CF Eaton Centre & 122 & 98 & 73 & 53 & $-40.2 \%$ & $-45.9 \%$ \\
\hline Sherway Gardens* & 3 & 8 & 19 & 28 & $533.3 \%$ & $250.0 \%$ \\
\hline Erin Mills Town Centre & 14 & 25 & 13 & 13 & $-7.1 \%$ & $-48.0 \%$ \\
\hline CF Fairview Mall & 13 & 16 & 13 & 16 & $0.0 \%$ & $0.0 \%$ \\
\hline CF Markville & 24 & 15 & 22 & 16 & $-8.3 \%$ & $6.7 \%$ \\
\hline Pickering Town Centre & 23 & 15 & 32 & 12 & $39.1 \%$ & $-20.0 \%$ \\
\hline Square One Shopping & & & & & & \\
Centre & 69 & 109 & 51 & 57 & $-26.1 \%$ & $-47.7 \%$ \\
\hline Scarborough Town Centre & 51 & 45 & 53 & 46 & $3.9 \%$ & $2.2 \%$ \\
\hline Upper Canada Mall & 22 & 11 & 22 & 11 & $0.0 \%$ & $0.0 \%$ \\
\hline Yorkdale Shopping Centre & 30 & 49 & 63 & 89 & $110.0 \%$ & $81.6 \%$ \\
\hline
\end{tabular}

* In 2014 Sherway Gardens was undergoing a significant renovation which resulted in a significant drop in leasable retail units and heavily impacted the trade area definition.

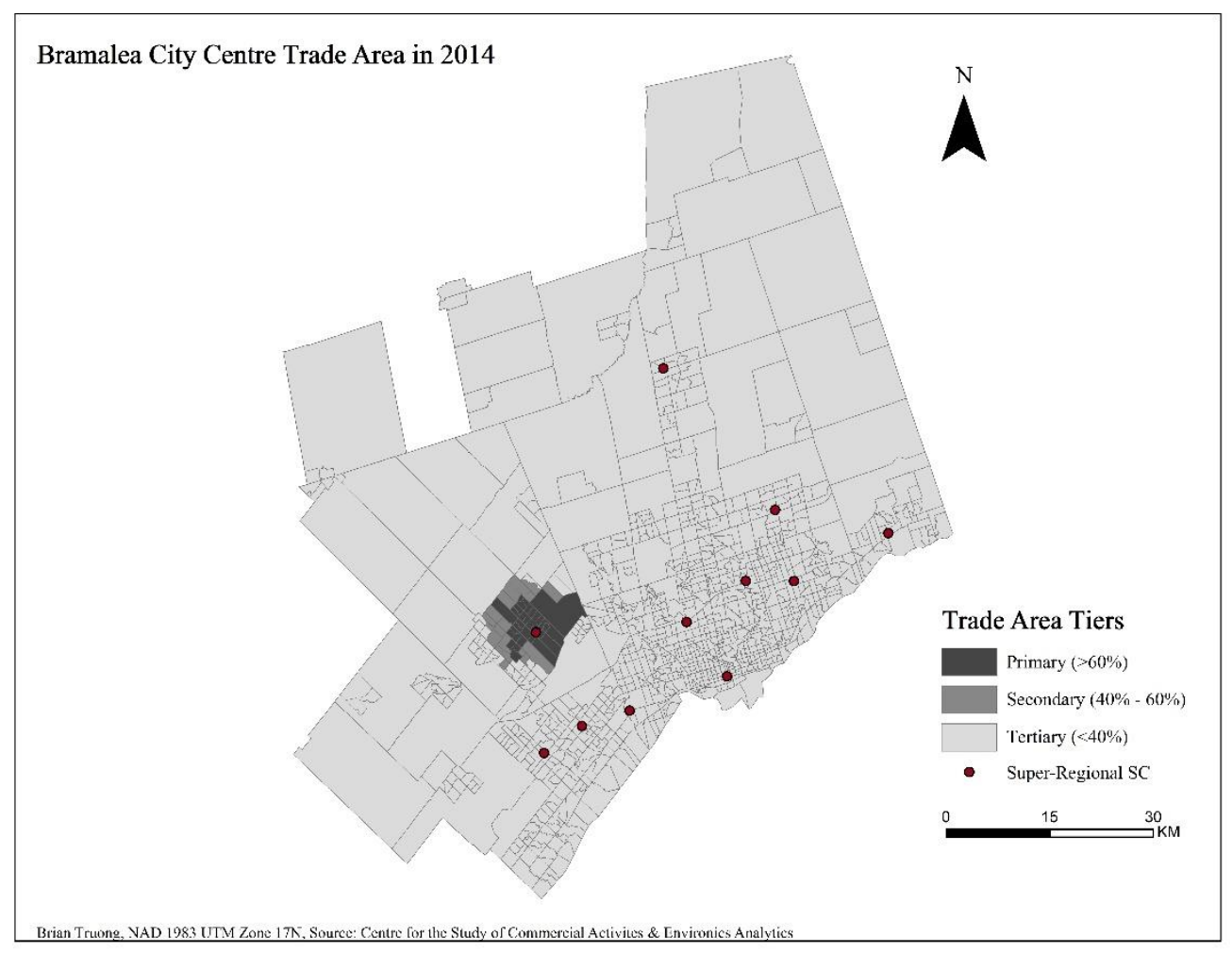

Figure 4.1 - Huff Model derived trade area for Bramalea City Centre in 2014. 


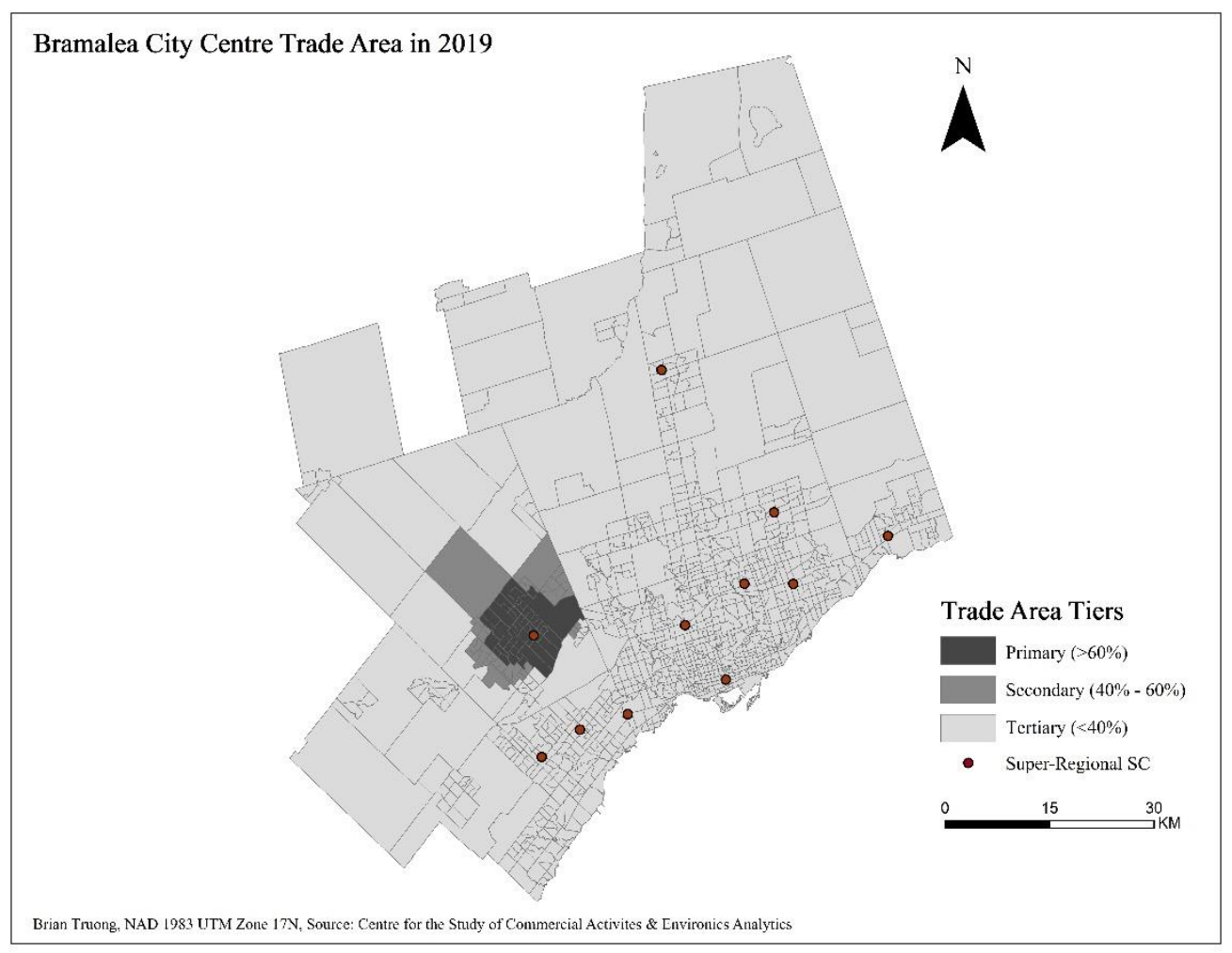

Figure 4.2 - Huff Model derived trade area for Bramalea City Centre in 2019.

\subsubsection{CF Toronto Eaton Centre}

The Toronto Eaton Centre, located in downtown Toronto, is perhaps one of the most unique and highly trafficked super-regional shopping centres in North America (Retail Council of Canada, 2018). In 2014, the Eaton Centre underwent a renovation of the old Sears unit, which transitioned to Nordstrom in 2019. Aside from that renovation there has not been much change to Eaton Centre's retail sq. ft. The surrounding shopping centres have however been expanding. Figure 4.3 shows Eaton Centre's initially dominant trade area in 2014, which accounts for most of the south part of Toronto extending to the east and west neighbourhoods. Figure 4.4 shows Eaton Centre's 2019 trade area, which shows a visually smaller trade area due to the expansion of surrounding shopping centres. 


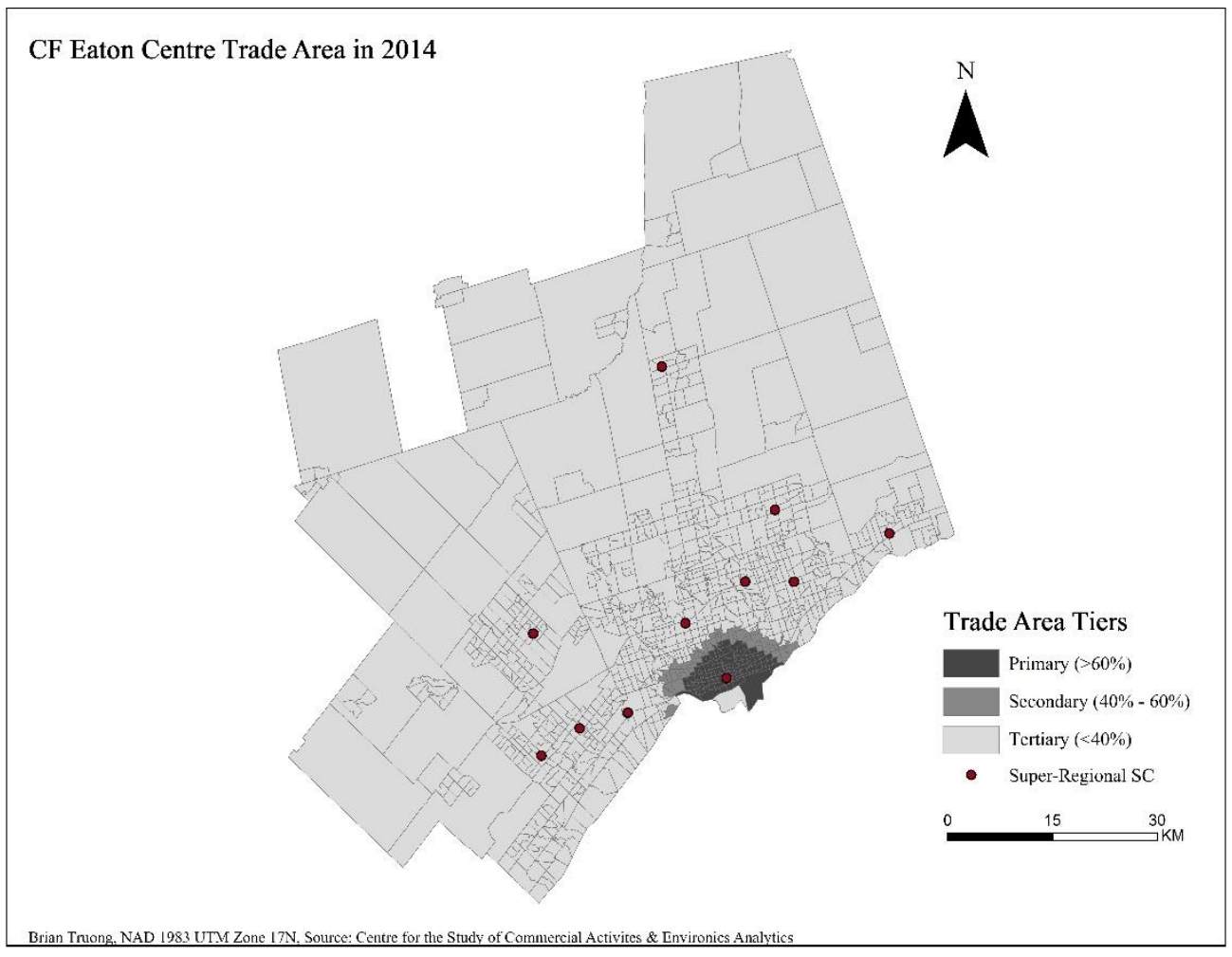

Figure 4.3 - Huff model derived trade area for CF Toronto Eaton Centre in 2014.

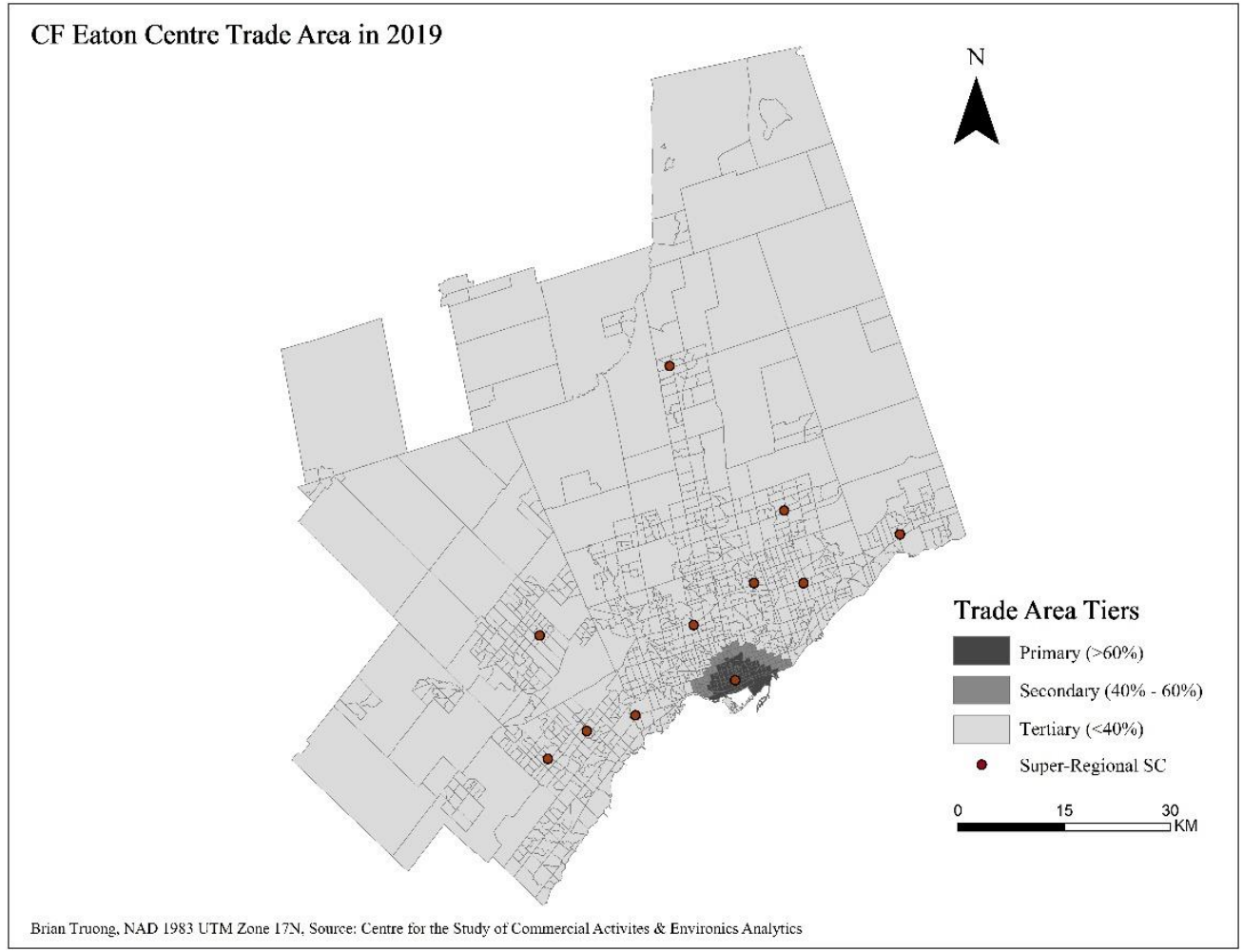

Figure 4.4 - Derived Huff model trade area for CF Eaton Centre in 2019. 


\subsubsection{Sherway Gardens}

Sherway Gardens was undergoing a renovation during 2014, which resulted in a loss of measurable retail space, thus reducing its influence in the surrounding area. Figure 4.5 highlights Sherway Garden's trade area during renovations, which shows a small trade area that results in single-digit census tracts in both the primary and secondary trade areas. This is because of the drop in leasable area due to the renovation as well as increased vacancies in the food court. During the renovation period Sherway Gardens moved the location of its food court to the new expansion (Cadillac Fairview, 2019), that resulted in tenants in their old food court not renewing their leases. Between 2014 and 2019, Sherway Gardens completed their renovation and introduced plenty of new FS options throughout the shopping centre. 


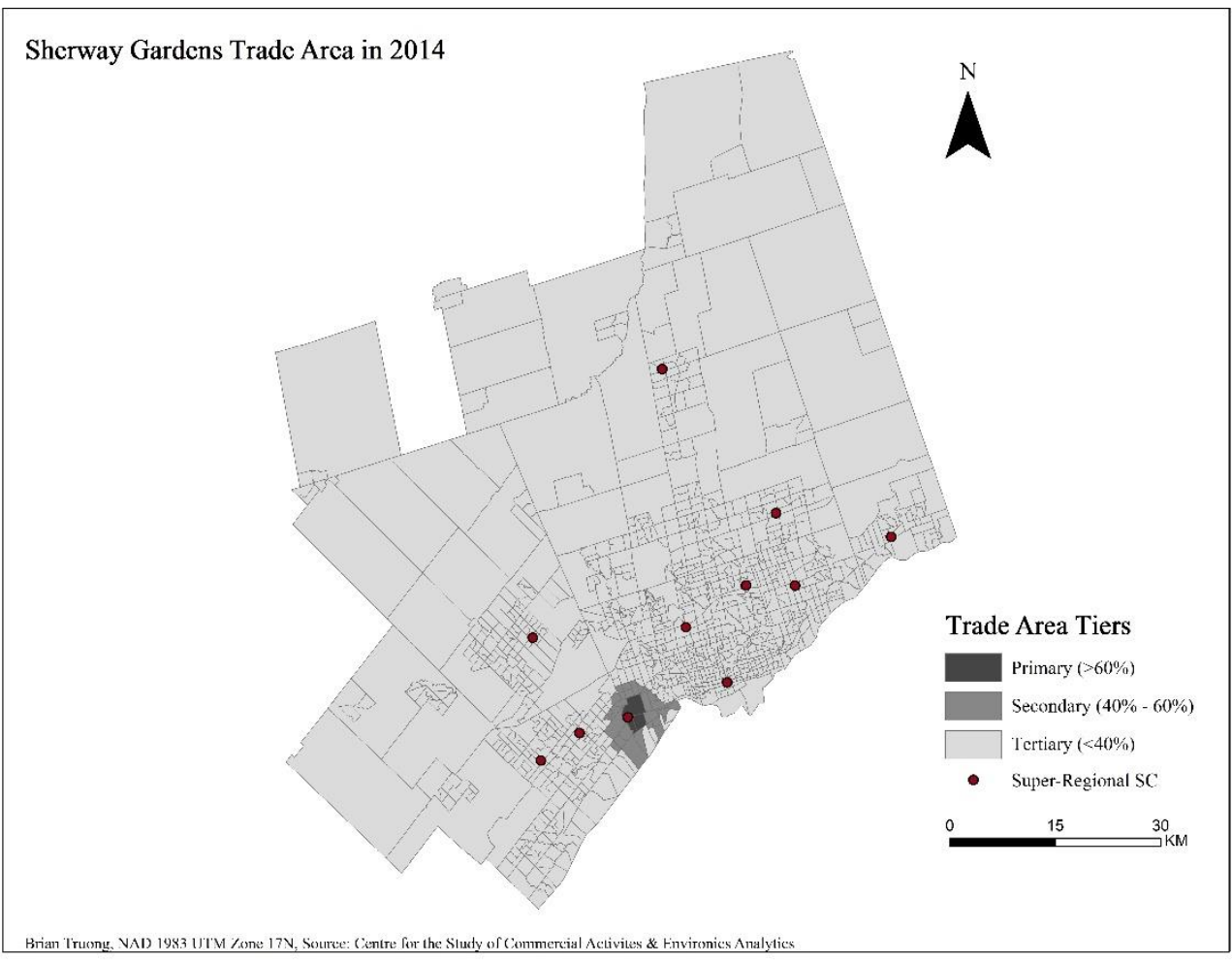

Figure 4.5 - Derived Huff model trade of Sherway Gardens in 2014

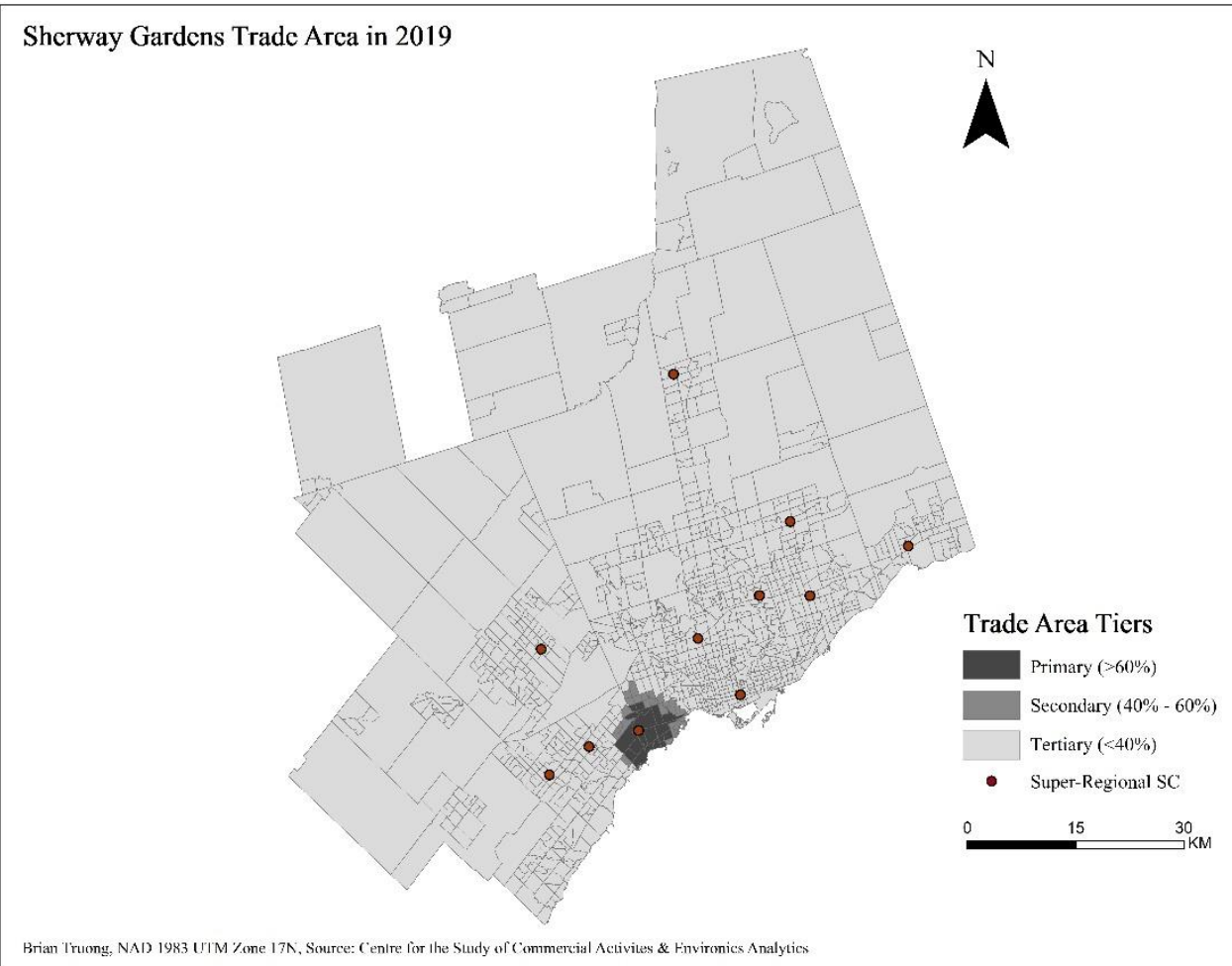

Figure 4.6 - Derived Huff model trade area of Sherway Gardens in 2019. 


\subsubsection{CF Markville}

Between 2014 and 2019, CF Markville expanded a small portion of the shopping centre, introducing more retail space for patrons. CF Markville does not focus on FS as much as its competitors in the Toronto CMA, this is evident through the change of FS units that are counted between the study years (Table 4.1). Figure 4.7 shows a modest trade area that mainly covers portions of the City of Markham. Figure 4.8 shows CF Markville's trade in 2019, highlighting there has been little change to the overall trade area. With the trade still mainly covering the City of Markham. Reasons for the lack of change in trade area could be due to the similarity in space allocated to FS, especially as how the composite attractiveness variable was calculated, having a 60:40 ratio between non-FS and FS retailers. 


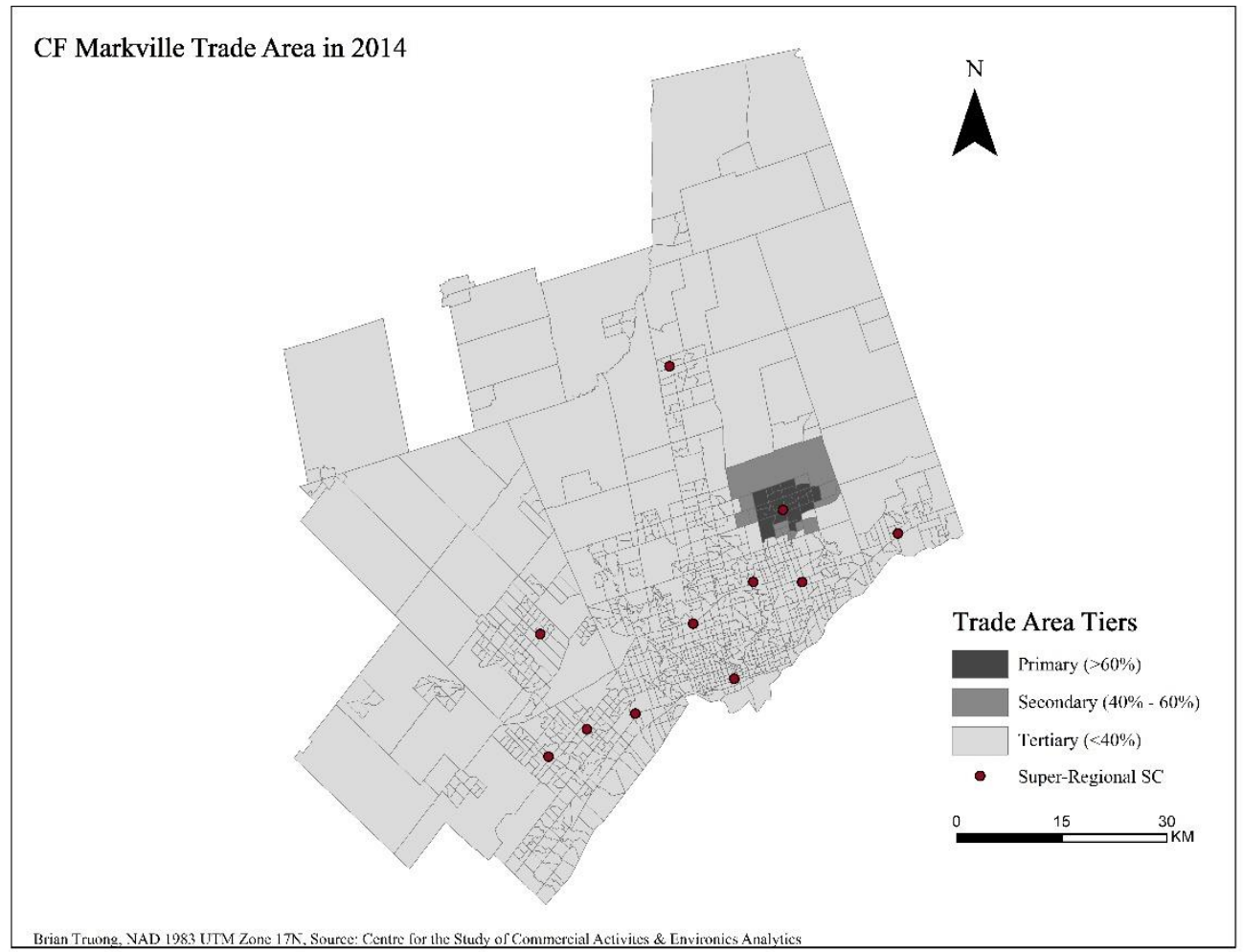

Figure 4.7 - Derived Huff model trade area for CF Markville in 2014.

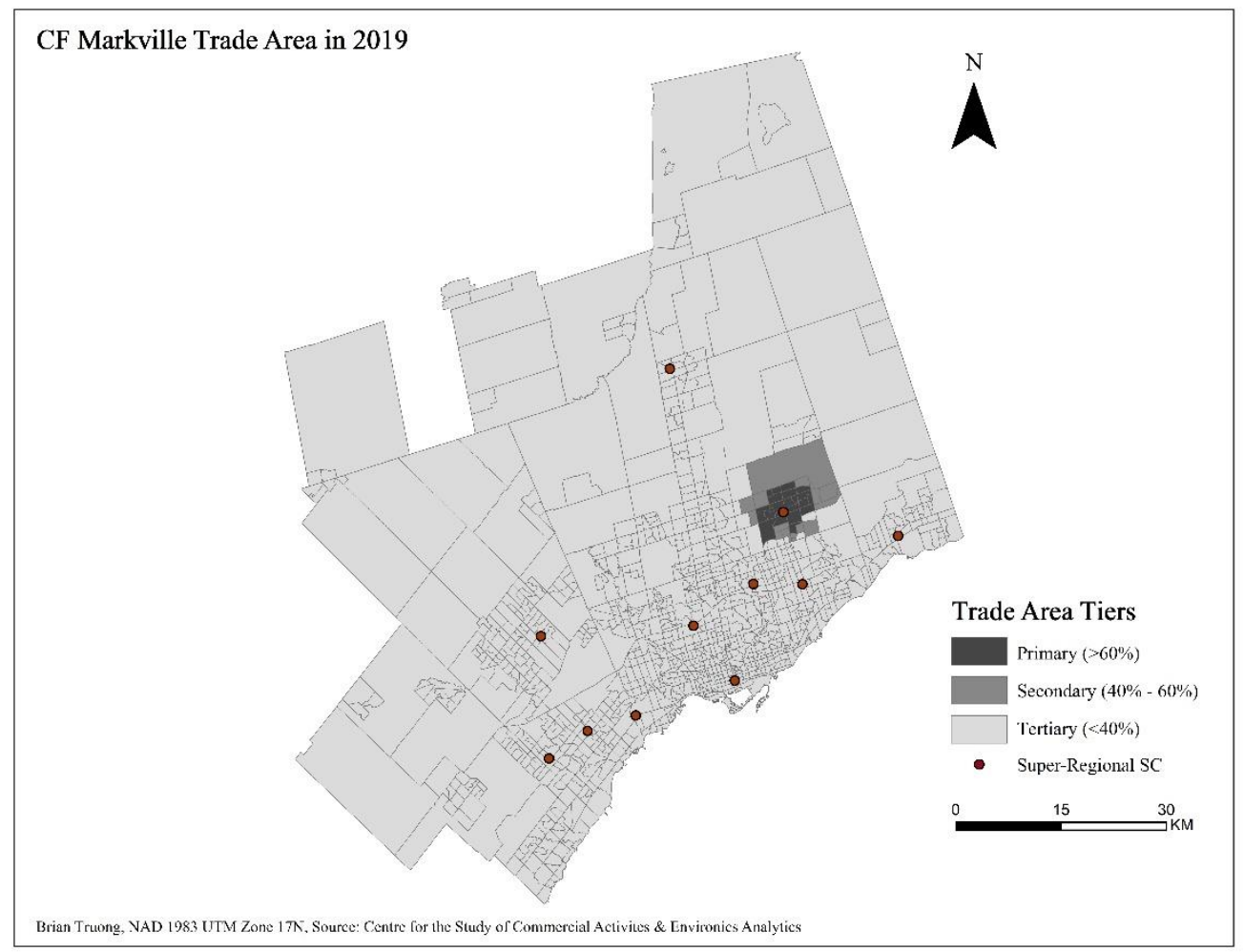

Figure 4.8 - Derived Huff model trade area for CF Markville in 2019. 


\subsubsection{Square One Shopping Centre}

Square One Shopping Centre is the largest shopping centre (excluding pad locations) in the Toronto CMA. Like many of the other super-regional shopping centres in the Toronto CMA, Square One had to deal with the sudden exit of Target from the Canadian market, the gap left by Target was quickly filled by Square One, which resulted in original space being split up into Indigo, Rec Room, and Uniqlo for the second floor. While the Food District occupied the ground floor. Throughout the course of the study period, Square One has gone through renovations and expansions, which resulted in a new luxury wing and a new anchor tenant; Holt Renfrew. Through the expansions and renovations, the shopping centre added a variety of new FS (Table 4.1).

Figure 4.11 shows Square One's massive trade area in 2014, which covers Erin Mills Town Centre's tertiary trade area (Figure 4.9). The massive trade area at the time can be attributed to Square One's vast retail space that it has both inside and outside of the shopping centre. In 2014, FS was not as predominant in the shopping as it is in 2019. Looking at the 2019 trade area of Square One (Figure 4.12) its secondary trade has become less significant. The smaller trade area is largely due to the 60:40 ratio that was used in creating the composite attractiveness variable. 


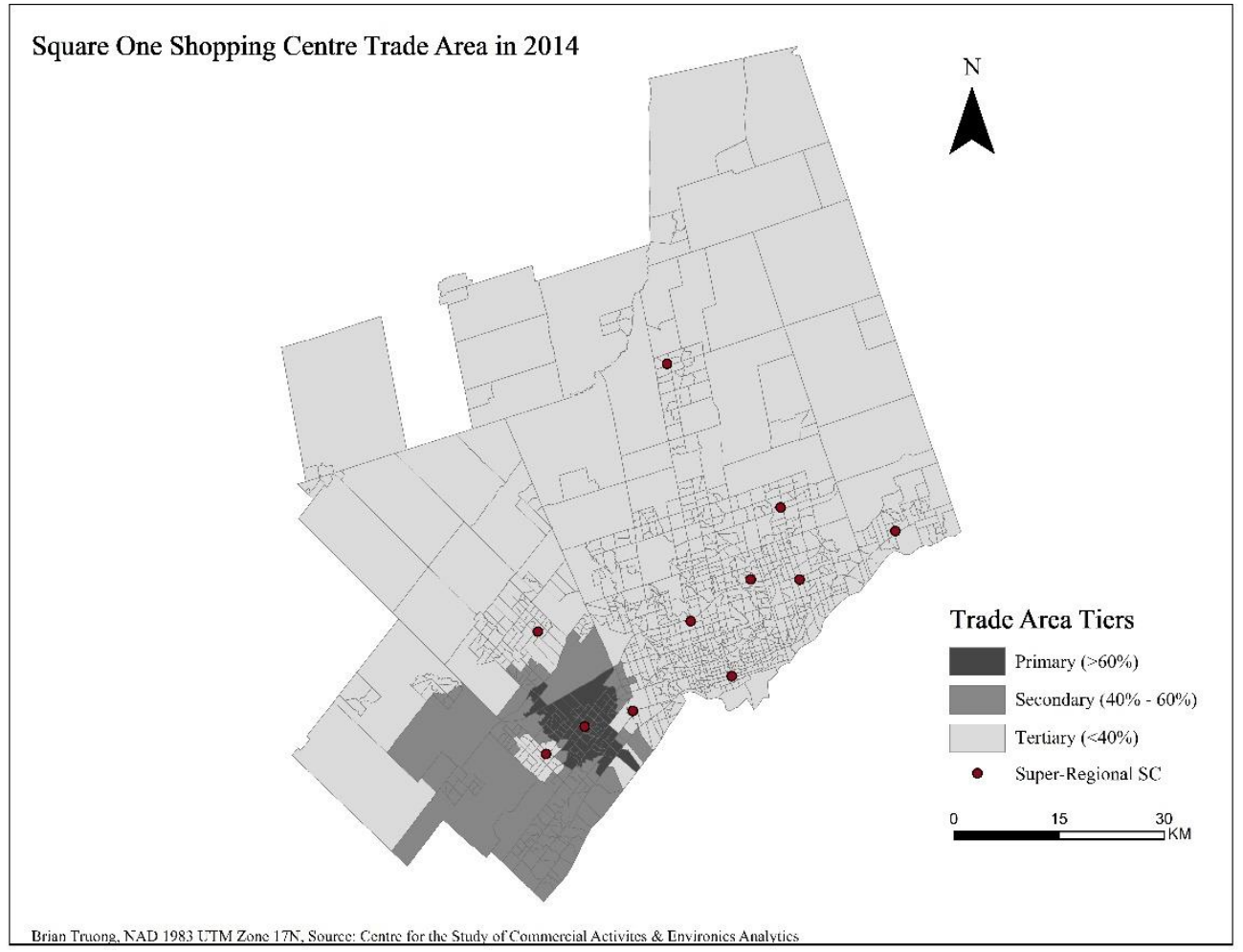

Figure 4.9 - Derived Huff model trade area for Square One Shopping Centre in 2014.

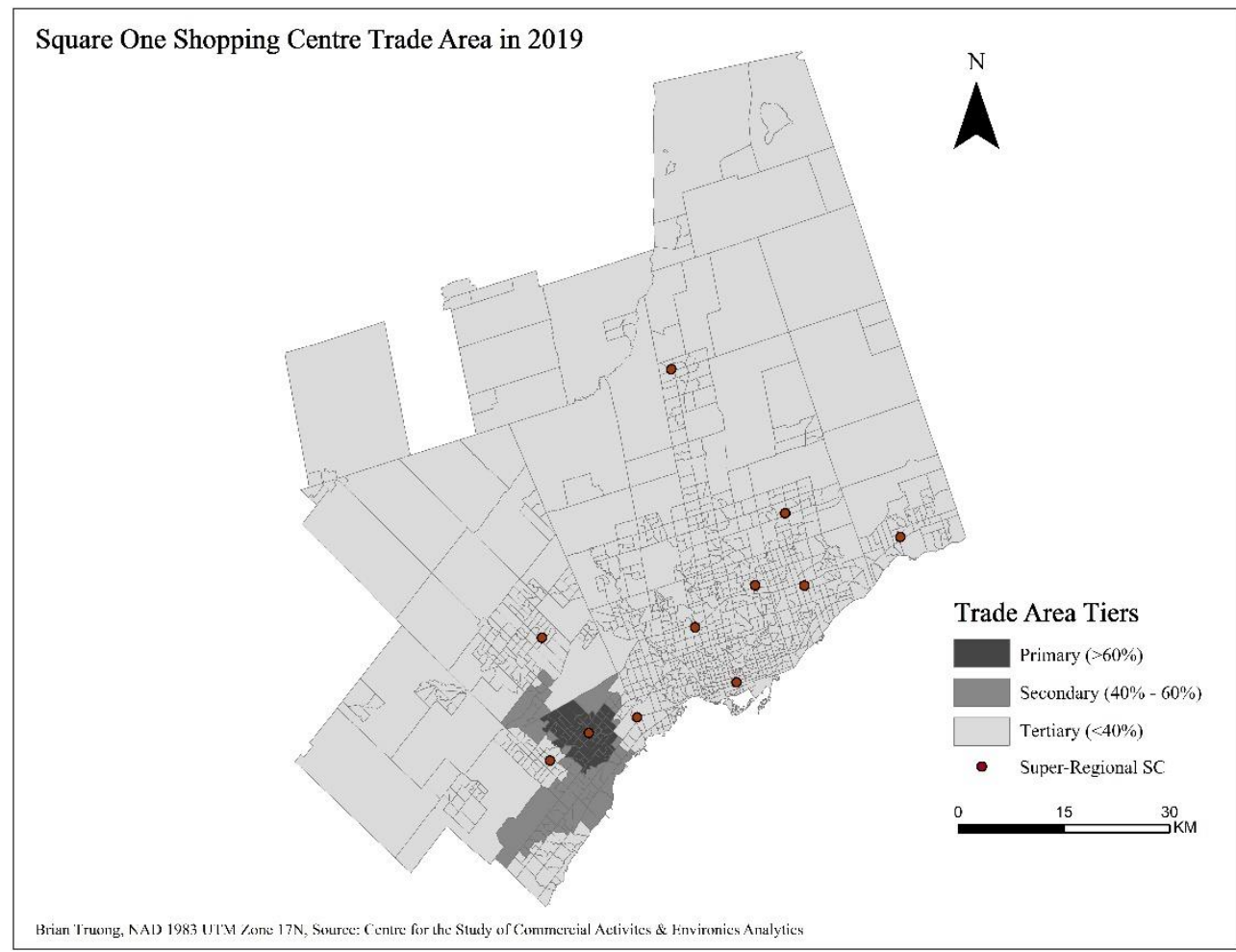

Figure 4.10 - Derived Huff model trade area for Square One Shopping Centre in 2019. 


\subsubsection{Erin Mills Town Centre}

Erin Mills Town Centre is the second of the two super-regional shopping centres in the Mississauga area; it is a mall that is often in the shadow of Square One Shopping Centre. In 2014, Erin Mills Shopping Centre had three anchors; Hudson's Bay, Sears, and Target. By 2019 Sears and Target had left, however, Walmart was able to fill the former Target anchor space. Erin Mills Town Centre did undergo a renovation of its food court in 2017 (Clay, 2017). Figure 4.9 shows the trade area for Erin Mills Town Centre, it is a relatively compact trade area extending towards the borders of Oakville. While the trade area that is shown in Figure 4.10 highlights a similar trade area that extends a bit more southwards. The lack of change in the trade areas can attributed to the lack of change in FS in the shopping centre and in its pads. While the food court did receive a renovation, the renovation itself served merely as a facelift for the shopping centre. While not adding any new FS retailers to the shopping centre. The loss of an anchor tenant also affects its trade area, though the trade area remains quite compact.

A reason that can explain why Erin Mills Town Centre has such a compact trade is by looking at Figure 4.11, which shows Square One Shopping Centre's primary trade area in 2014. Square One's secondary trade area completely encompasses Erin Mills Town Centre's trade area. This reinforces the notion of Erin Mills Town Centre being in the shadow of Square One. 


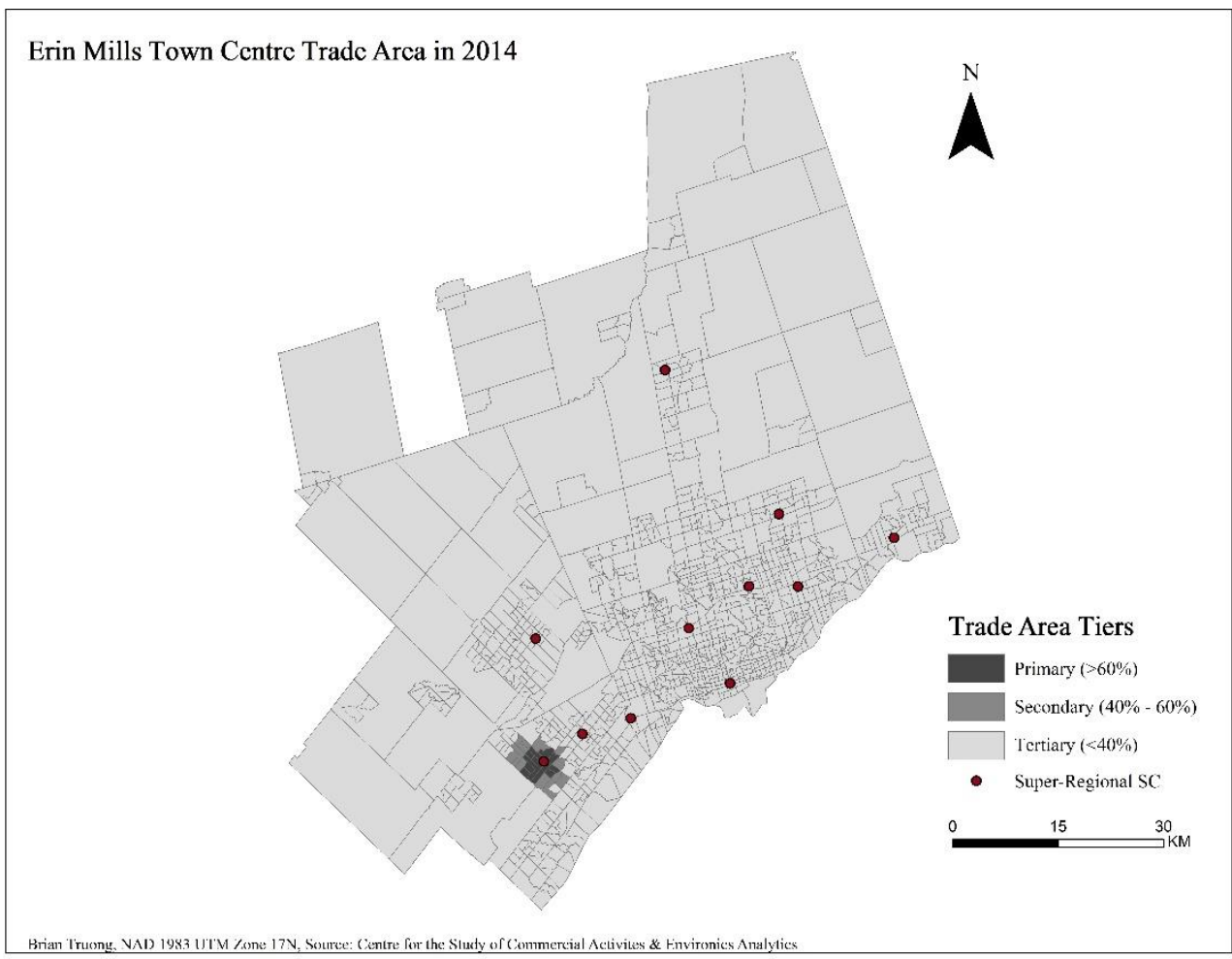

Figure 4.11 - Derived Huff model trade area for Erin Mills Town Centre in 2014.

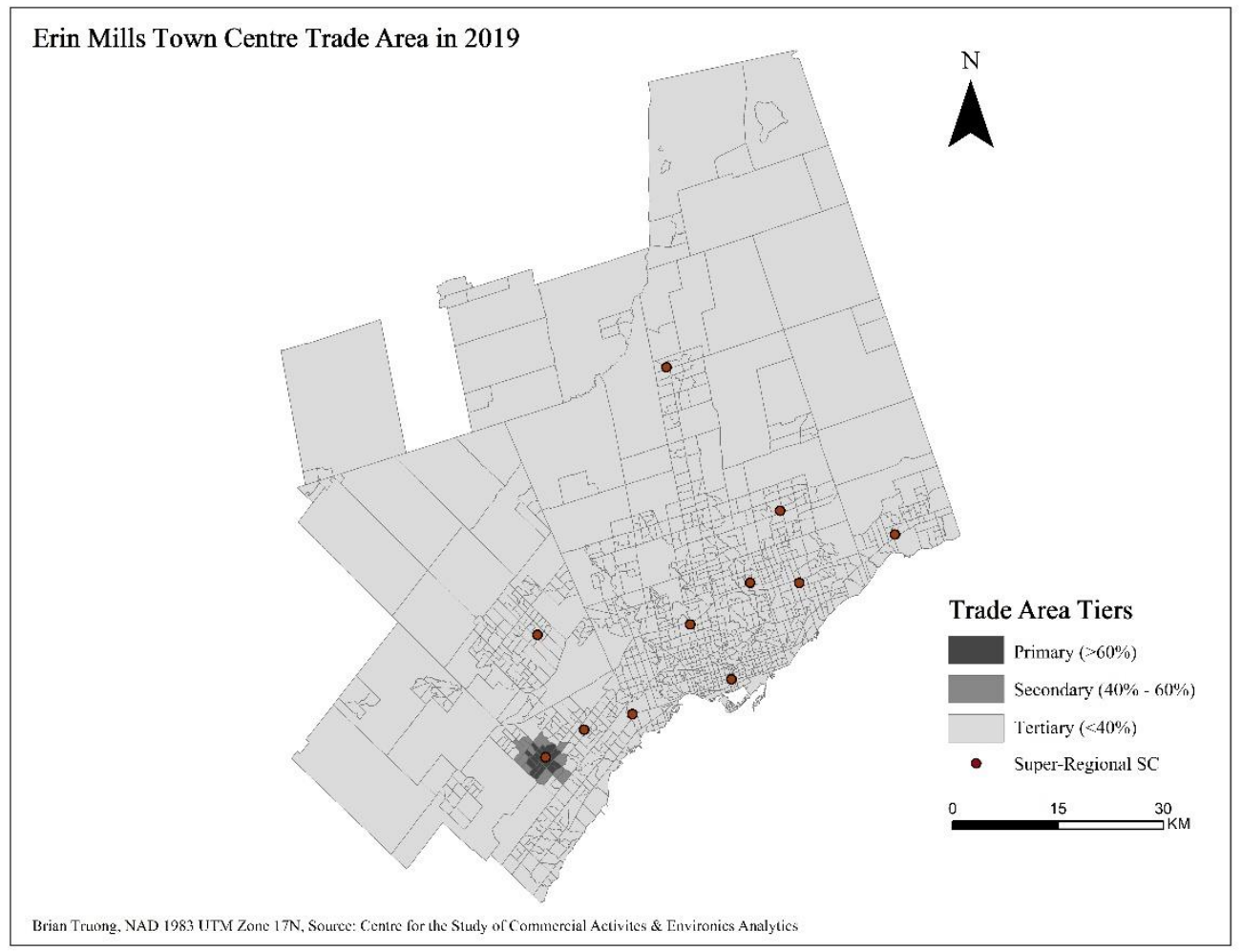

Figure 4.12 - Derived Huff model trade area for Erin Mills Town Centre in 2019. 


\subsubsection{Upper Canada Mall}

The first shopping centre in the Toronto CMA to introduce a food hall was Upper Canada Mall, utilizing the entire vacant unit that was left by Target's departure. It is the CMA's northernmost shopping centre, in Aurora. According to Table 4.1 Upper Canada Mall has seen significant growth in most FS categories over the five years. Upper Canada Mall shares some similarities with Erin Mills Town Centre in 2014, as it had the same three anchors only to lose two of them. In this case Upper Canada Mall repurposed Target's unit into a food hall.

The trade area of Upper Canada Mall in 2014 (Figure 4.13) mainly covers Aurora and the surrounding area. What's unique with Upper Canada Mall is that even though this mall is within the Toronto CMA, it is relatively isolated, with multiple municipalities separating it from the closest super-regional shopping centre. Due to its isolation in terms of distance away from other shopping, it makes it more difficult for the changes of competing shopping centres to affect its trade area. However, the isolation of Upper Canada Mall may also be a reason why there was no change in Upper Canada Mall's trade area after five and a new food hall (Figure 4.14). 


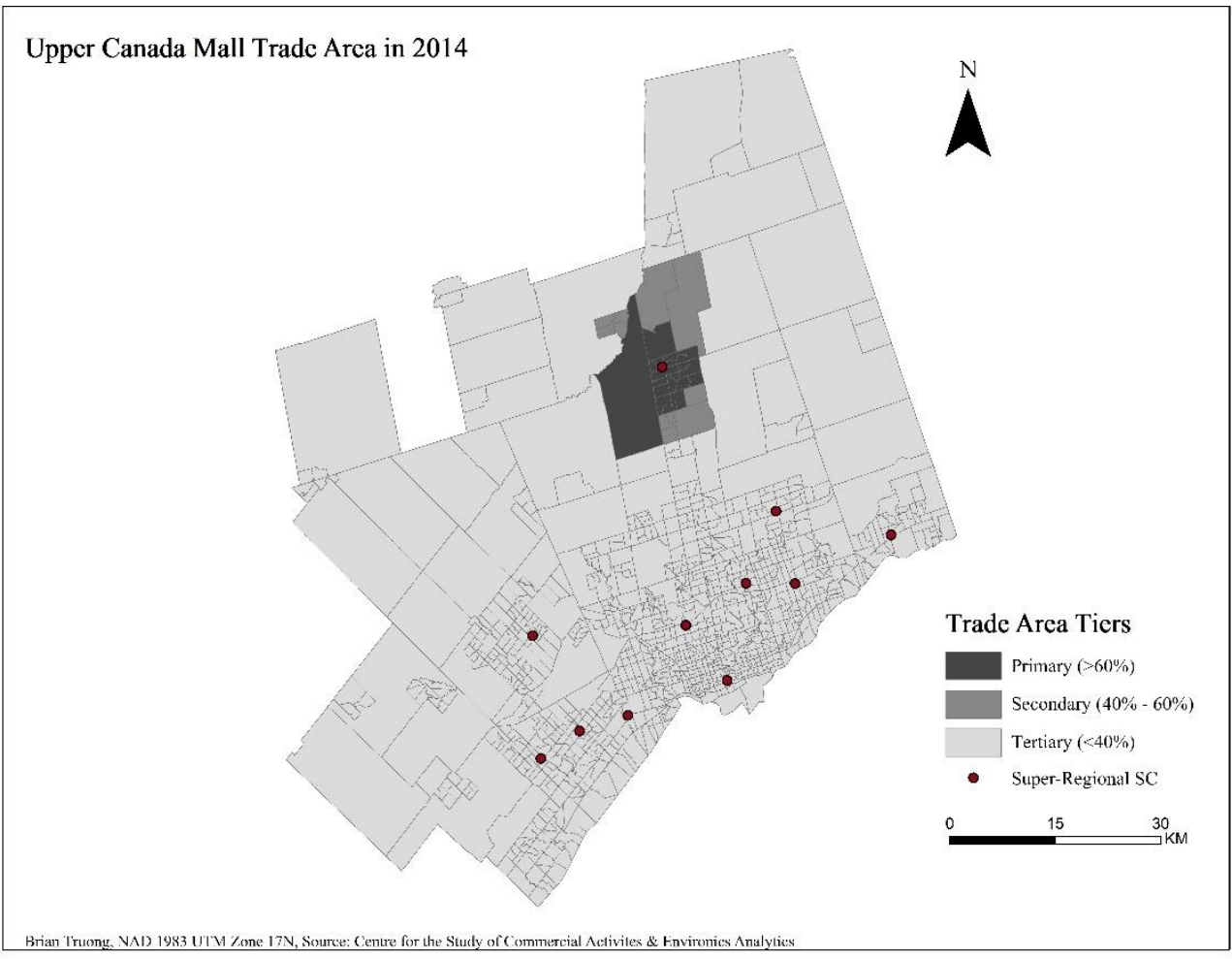

Figure 4.13 - Derived Huff model trade area for Upper Canada Mall in 2014.

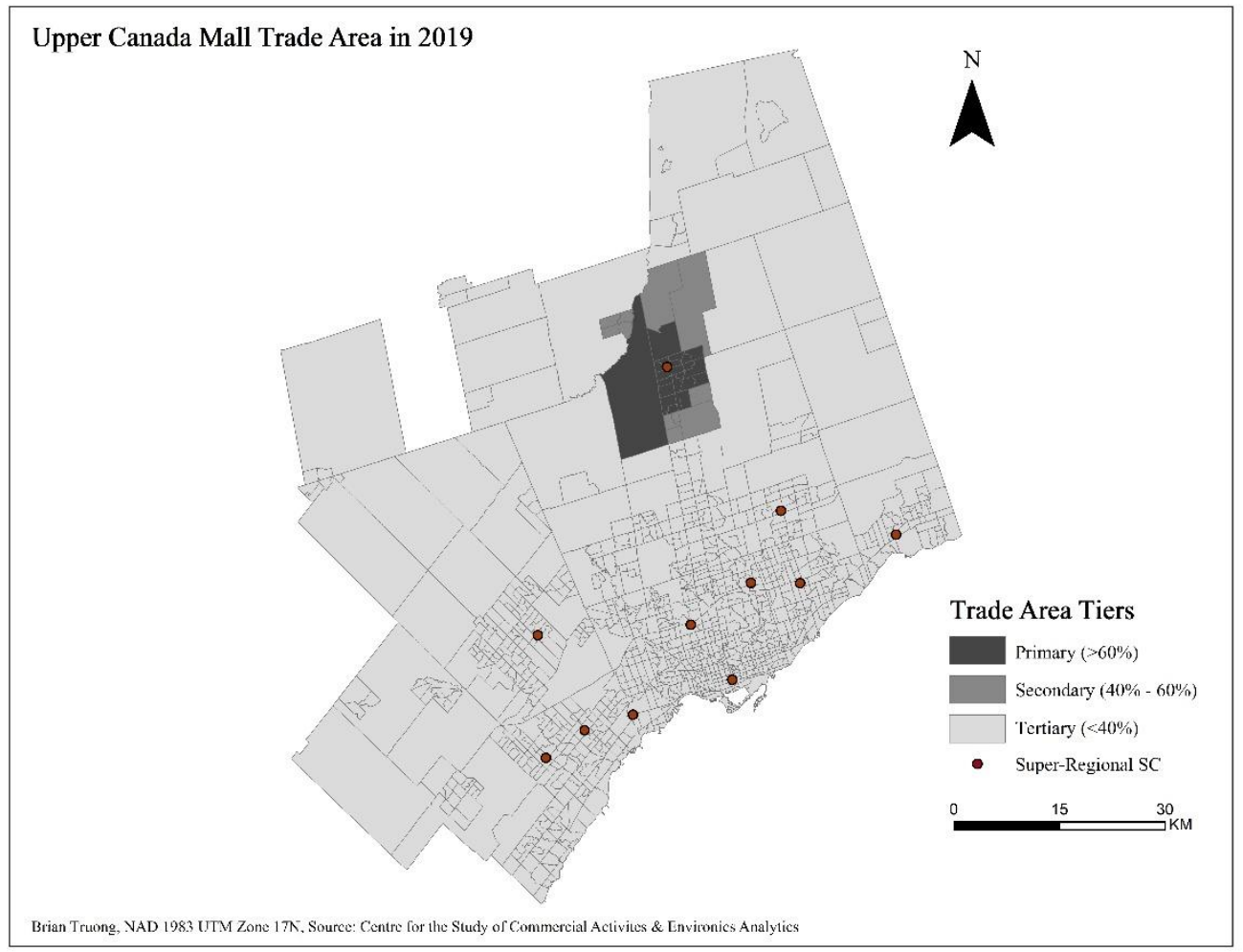

Figure 4.14 - Derived Huff model trade area for Upper Canada Mall in 2019. 


\subsubsection{CF Fairview Mall}

CF Fairview is the smallest super-regional shopping centre in the Toronto CMA. With two of the more popular super-regional shopping centres on the East and West sides of the shopping centre; Scarborough Town Centre and Yorkdale Shopping Centre. Over the study period, Fairview Mall lost an anchor tenant; Sears, which remained vacant in 2019. Other than the loss of an anchor tenant, there has not been much change in Fairview Mall. The trade area for Fairview mall in 2014 (Figure 4.14) shows a relatively small trade area. That trade area does not change at all during 2019. It is interesting to see how there is lack of change in the trade even though an anchor tenant became vacant. 
CF Fairvicw Mall Trade Arca in 2014

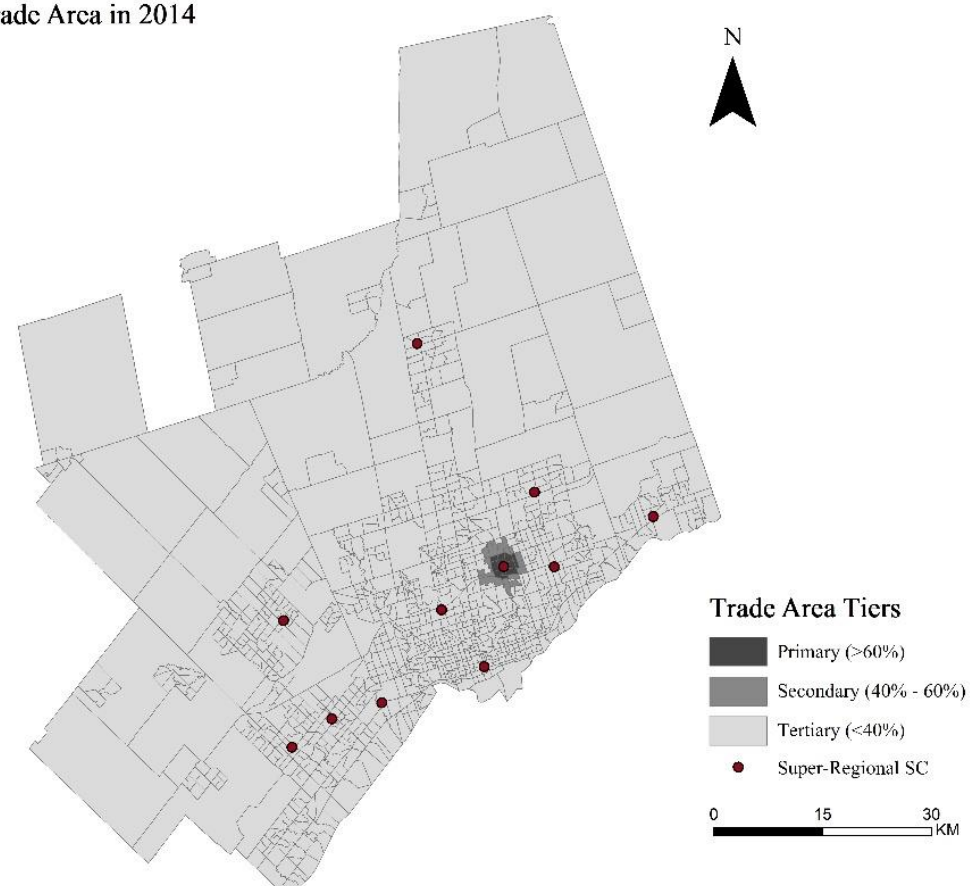

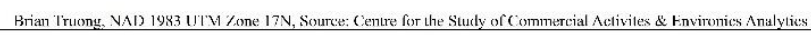

Figure 4.15 - Derived Huff model trade area for CF Fairview Mall in 2014.

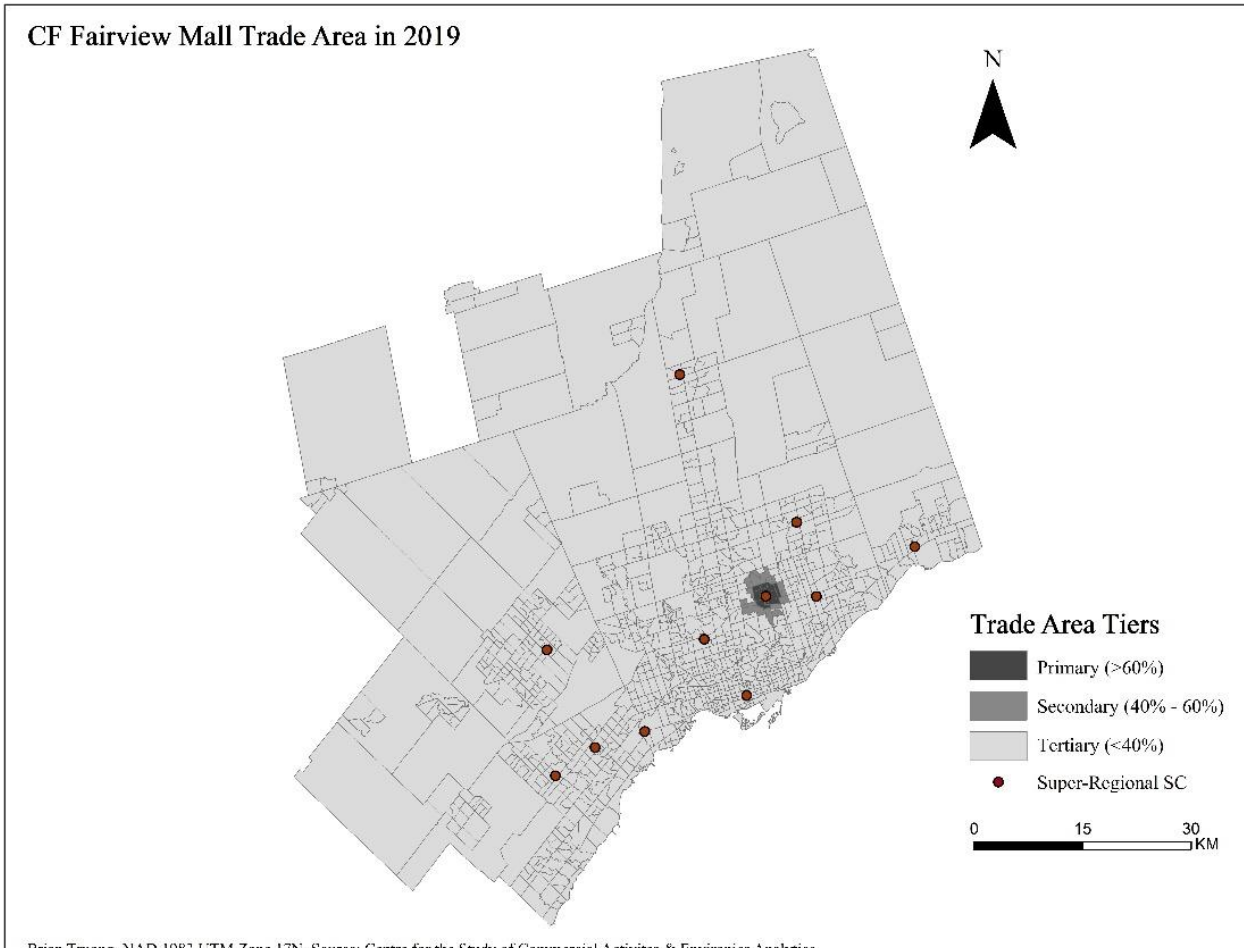

Brian Truong, VAD 1983 UTM Zone 17N, Source: Centre for the Study of Conmercial Activites \& Environics Analytics

Figure 4.16 - Derived Huff model trade area for CF Fairview Mall in 2019. 


\subsubsection{Yorkdale Shopping Centre}

Aside from being the most productive shopping centre in North America (Retail Council of Canada, 2018), Yorkdale shopping centre is also perhaps one of the most innovative shopping centres in the Toronto CMA. While Yorkdale does not have any food hall, it has been innovative with the type of retailers that have leased units in the shopping centre. In 2017, Yorkdale unveiled a new retail space called CONCEPT which was a short-lease (pop-up) space for retailers (Retail Insider, 2017). In the first iteration of the space, it showcased several local and unique FS in the space. While it has since become a space for a mix of retailers both FS and nonFS it remains a unique experience for patrons of Yorkdale. In terms of trade area change, in 2014 Yorkdale had a reasonably sized trade area that covered most of North York (Figure 4.16). While in 2019, the trade area grew larger (Figure 4.17). Changes to Yorkdale's trade area could be attributed to the expansion of the shopping centre and as well as the introduction of more FS throughout the shopping centre. 


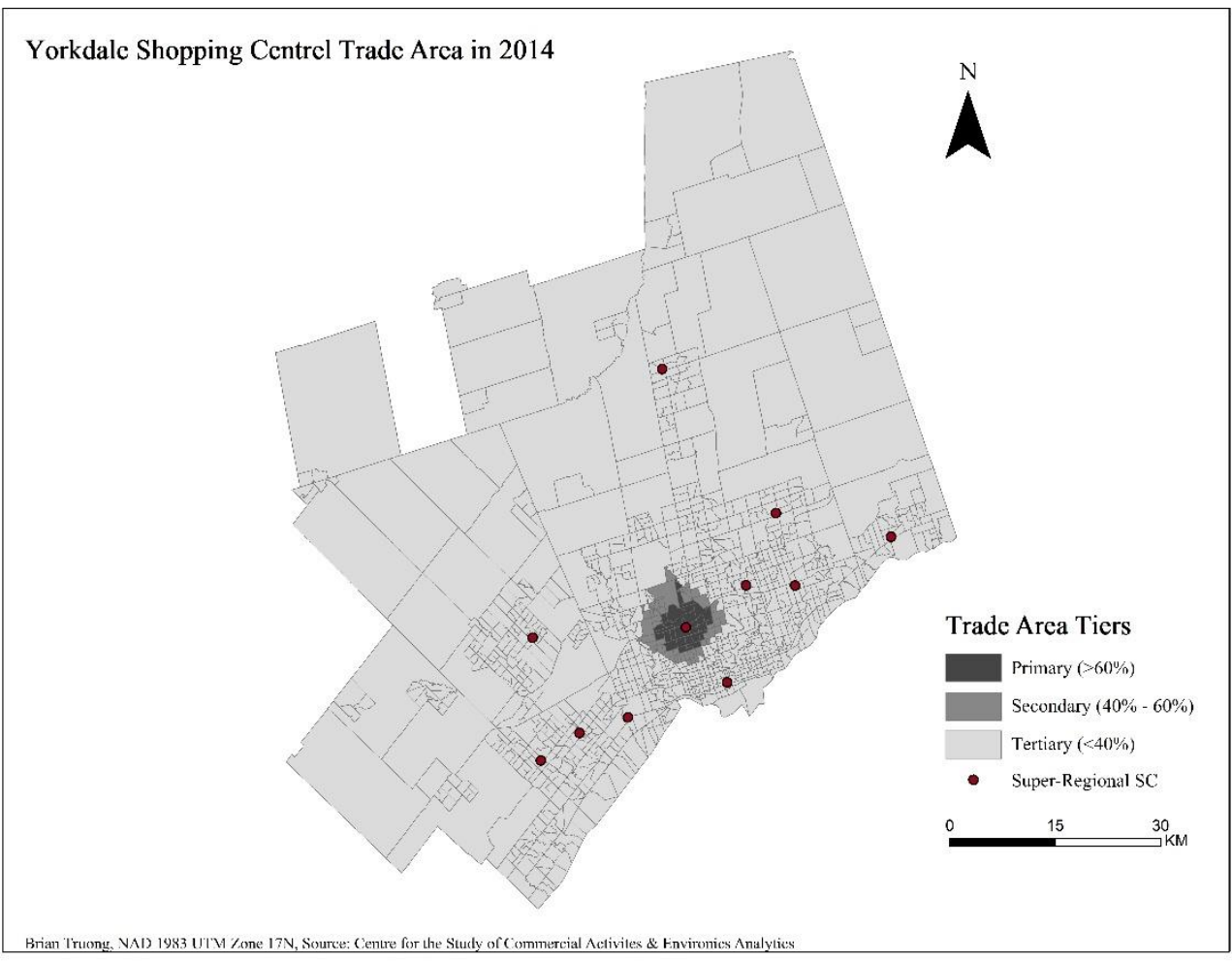

Figure 4.17 - Derived Huff model trade area for Yorkdale Shopping Centre in 2014.

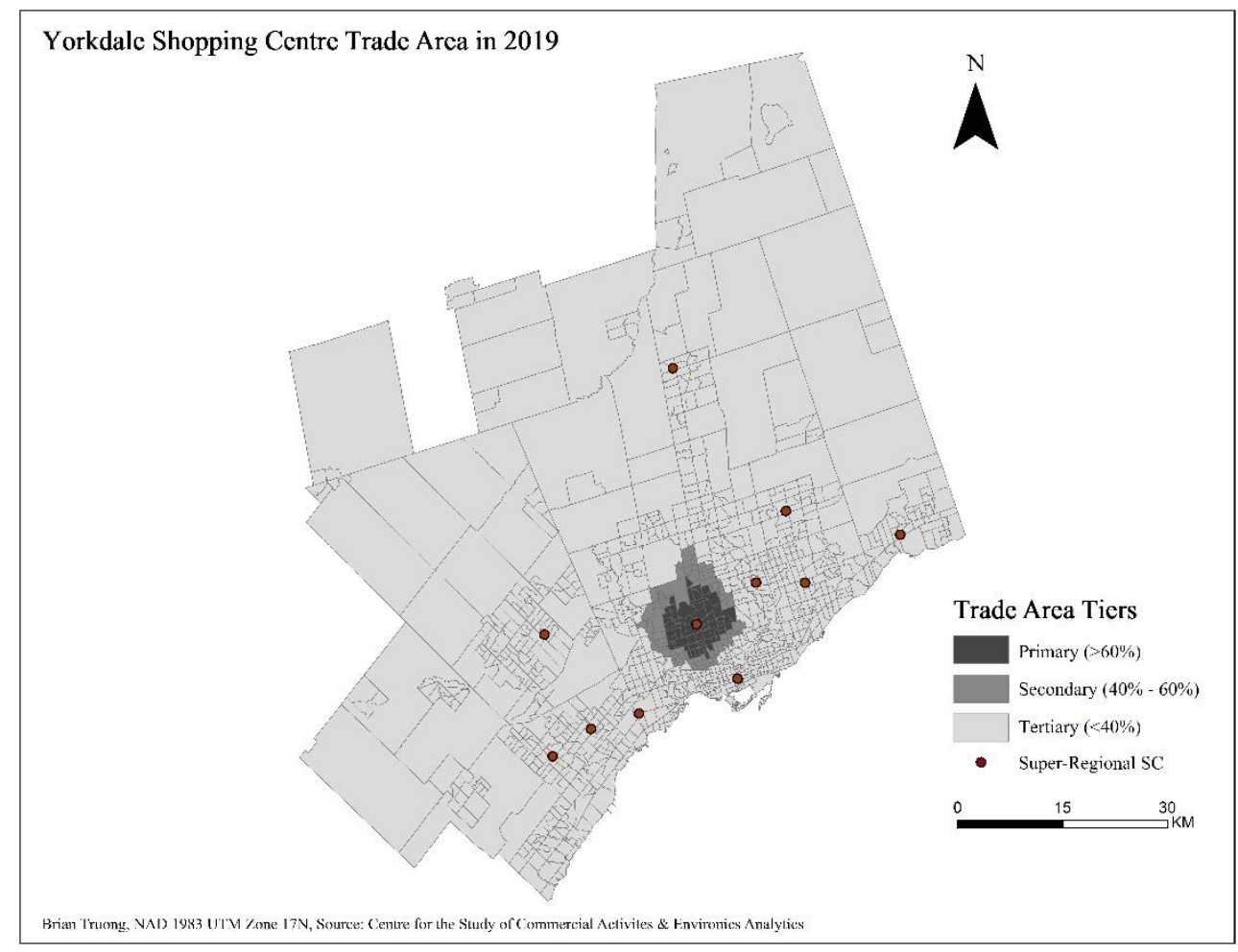

Figure 4.18 - Derived Huff model trade area for Yorkdale Shopping Centre in 2019. 


\subsubsection{Scarborough Town Centre}

Like many other shopping centres in the City of Toronto, Scarborough Town Centre is found along a primary subway line. Out of the other the shopping centres that are found along TTC subway lines, Scarborough Town Centre is by the largest in terms of sheer retail size. In 2014, Scarborough Town Centre had quite a diverse mix of FS in the shopping centre and within the surrounding pad locations along with three anchor locations to attract consumers. The trade area in Figure 4.18 shows that in 2014 Scarborough Town Centre was attracting consumers throughout Toronto's East end. Between 2014 and 2019, Scarborough Town Centre opened expanded its food court, opening up a rebranded food court called Taste Markt that focuses more on Fast-Casual dining; however there were still Speed Eating establishments within it (Oxford Properties, 2019). Scarborough Town Centre also re-purposed the space previously occupied by the old food court placing new types of FS establishments in that spot, ranging from Premium Casual to Impulse. Though Scarborough Town Centre lost two of its anchor tenants, it has invested heavily in FS both in and out of the shopping centre (Figure 4.19). Overall the trade area of Scarborough Town Centre still covers most of the East side of Toronto. FS in this Scarborough Town Centre had a positive impact on its trade area, especially as traditional anchors become vacant in the shopping centre. 


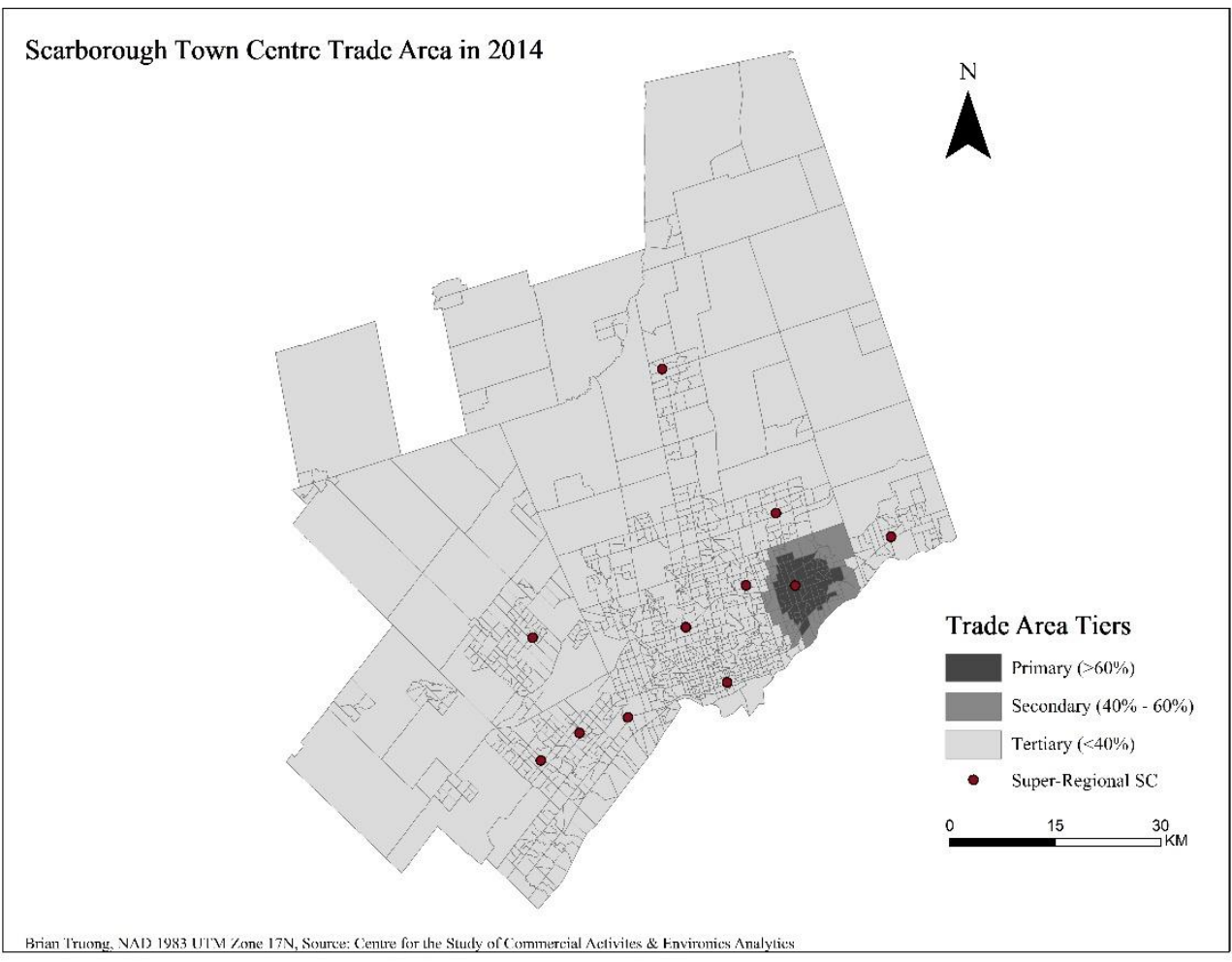

Figure 4.19 - Derived Huff model trade area for Scarborough Town Centre in 2014.

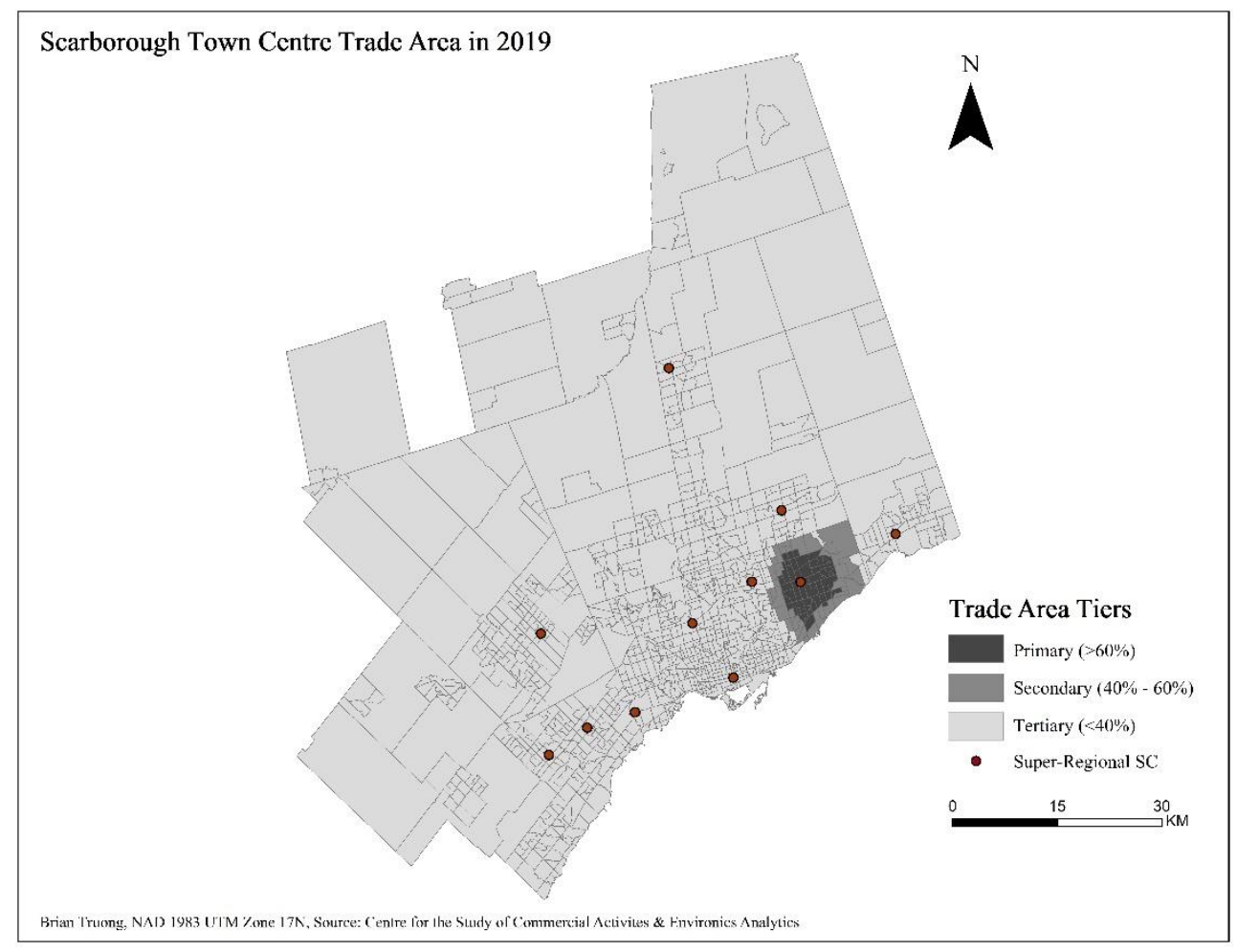

Figure 4.20 - Derived Huff model trade area for Scarborough Town Centre in 2019. 


\subsubsection{Pickering Town Centre}

Pickering Town Centre has largely remained the same over the past five years. The shopping centre lost two anchor tenants throughout the five years; Target and Sears. The shopping centre managed to fill in the space left by Target by splitting up that space for retailers, however the Sears remains vacant. Figure 4.20 shows Pickering Town Centre's trade area in 2014 is mainly in the municipality of Pickering, the west end of the trade area borders Scarborough Town Centre's trade area. The increases in FS during the five-year period and the diversification of its old Target unit has contributed to the growth of the trade area in 2019 (Figure 4.21). In 2019, the trade area of the shopping centres does not change much, as Scarborough Town Centre remains an extreme competitor for Pickering Town Centre. However, Pickering Town Centre's trade area has grown to encompass all of Pickering. 


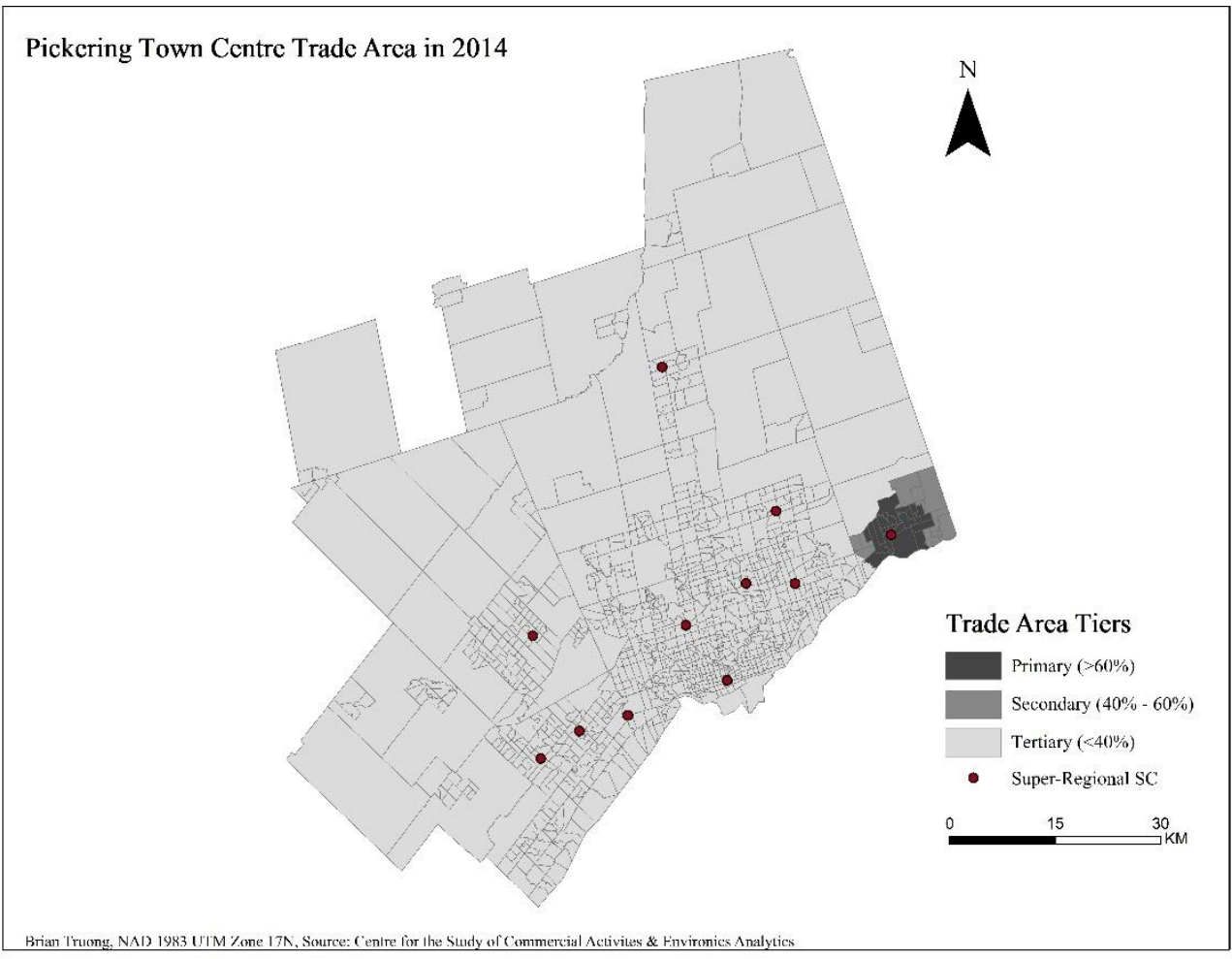

Figure 4.21 - Derived Huff model trade area for Pickering Town Centre in 2014.

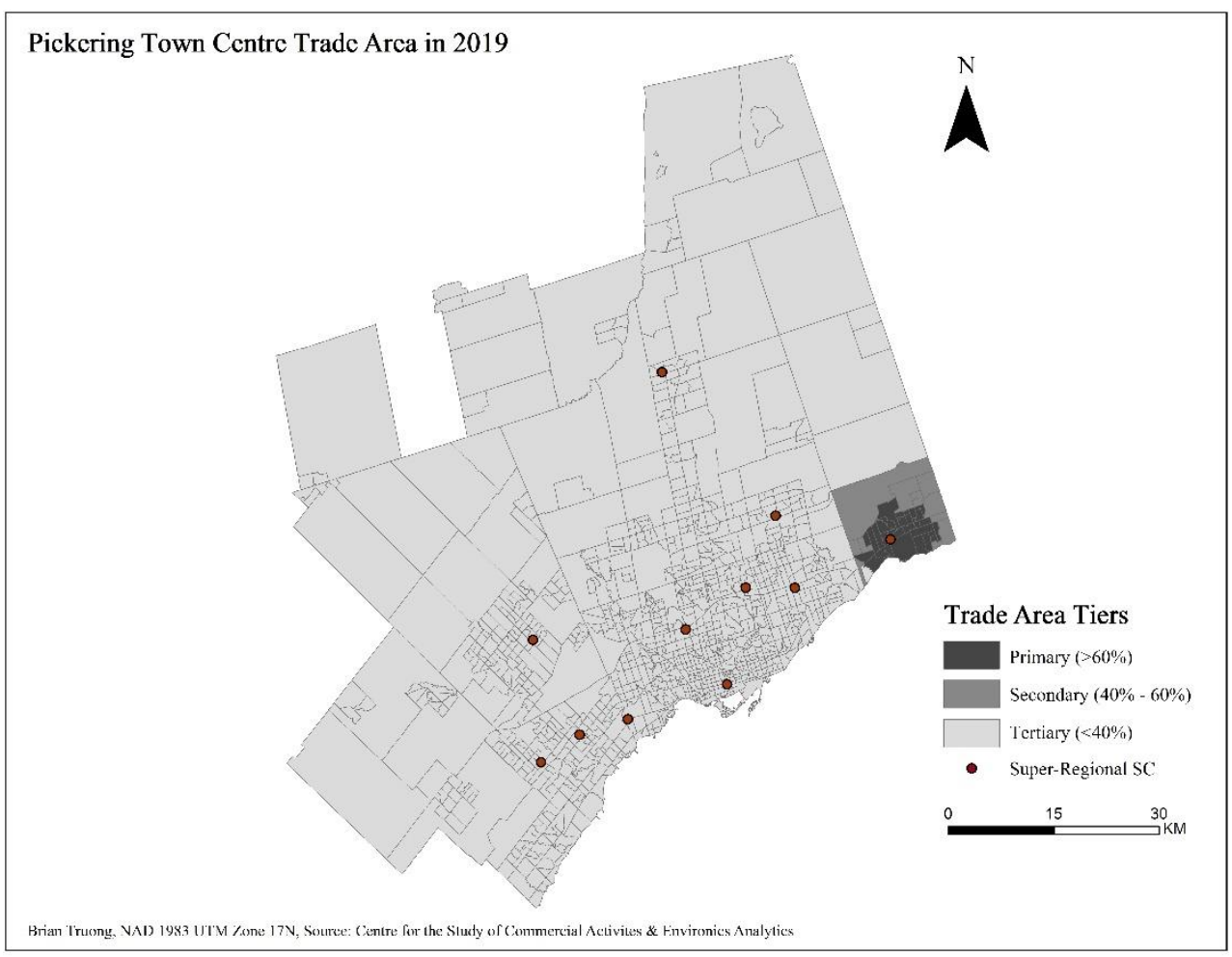

Figure 4.22 - Derived Huff model shopping centre for Picking Town Centre in 2019. 


\subsection{The Future of Food Services within Shopping Centres}

There has been constant change in FS in super-regional shopping centres across the Toronto CMA, with some shopping favouring a marked increase in FS. Table 4.1 shows an overall increase in FS within all shopping centres, the data between the five years are also supported through industry reports from ICSC and JLL (ICSC, 2017; JLL Foodservice Consulting, 2019). FS categories like Impulse and Gourmet foods are more likely to appear in lower-tiered shopping centres as they are easier to integrate into shopping centres due to smaller retail footprint. While FS categories that are likely to use more space like Casual Dining and Premium Casual establishments will be harder to integrate into shopping centres. Though most of the super-regional shopping centres there has been atleast one anchor unit that became vacant, allowing it to be easier for shopping centres to integrate FS. Some shopping centres have already repurposed the empty space left by the anchor stores into a mix of FS and non-FS retailers.

Food halls which have so far appeared in two super-regional shopping centres seem to be an entity that can work within a super-regional shopping centre environment. However, significant investment is often required to repurpose the existing space or to create a new space. Food halls tend to work best in urban environments where the surrounding area is densely populated (ICSC, 2017). Both properties that introduced food halls were managed by Oxford Properties, while they share some similar tenants they still differ slightly through design. While food halls have yet to be common in shopping centres, it is still essential for food halls to remain an authentic experience for shopping centre patrons.

Fast-Casual FS has been growing over the five years in each of the super-regional shopping centres; it is a trend that continues to grow, especially as consumers are increasingly looking for healthier dining alternatives (Cushman \& Wakefield, 2019). Fast Casual dining is versatile in that it can occupy different types of space within the shopping centre. It does not need to be restrained by a shopping centre food court (Cadillac Fairview, 2019). It is expected that growth of Fast Casual should be with within the double-digit percentages in the coming five years. However, there was a rise of Speed Eating establishments with more incorporating Fast Casual routines into their ordering system. The most prominent example of this is McDonald's (Great Speculations, 2018), though there are other Speed Eating and Refuel and Relax chains 
that have been offering customization options for their patrons - blurring the lines of FS categories.

\section{Chapter 5. Conclusion \& Future Research}

\subsection{Limitations \& Assumptions}

Data availability was the most significant limitation of this study. Site plan information was used to collect the different types of stores and sq. $\mathrm{ft}$ in both 2014 and 2019. The problem with that was that not all site plans provided sq. $\mathrm{ft}$ information on its units, while some did provide sq. $\mathrm{ft}$ information however they were estimated sizes. The majority of the problems with site plan information were from site plans in 2014, Scarborough Town Centre and Upper Canada Mall did not have any sizing in the site plan. With those two shopping centres, the CSCA SCD was used as a supplement to fill in some missing sizes. Missing stores were identified by comparing the stores in the SCD with store listed on the site plan. However, the SCD does not include nonretail chains that could be in those shopping centres, thus estimated sizes of missing storefront were created. Shopping centres that were managed by 20 Vic Management also had site plans that were merely estimated sizes on the 100's. Due to estimated sizes being used, it was not a completely accurate representation of the overall retail size of the shopping at the time. In 2019 there were fewer problems that had to do with the site plan, the shopping centres that were associated with Cushman \& Wakefield; Erin Mills Town Centre and Pickering Town Centre did not have sizing information associated with the shopping centre. The same process to fill in missing sizes was used for these two shopping centres.

There were also some assumptions made with the secondary data sources in 2014. Data that were used to estimate sales potential for the CTs in 2014 were gathered from slightly different sources and different years. Both sources of data were gathered from Environics Analytics products, which combined various sources of data with the 2011 Census to create a projection for that year. Expenditure data were gathered from the HouseSpend 2015 database, while Average Household Income data was gathered from the DemoStats 2014 database.

This research utilized a 60:40 weighting scheme for the Huff model, which resulted in $60 \%$ of the weight going towards non-FS retailers and $40 \%$ of FS retailers. The weighting scheme is a subjective weighting scheme based on the current conditions of shopping centres. It 
was assumed that the purpose of a shopping centre is still primarily as a place to shop, rather than eat. This weighting scheme can be adjusted given additional data on consumer behaviour.

\subsection{Key Findings \& Recap}

There has been growth of FS in shopping centres from 2014 to 2019. The traditional shopping centre has been steadily declining as consumer behaviours have begun to shift towards the convenience of online platforms and services (Kunbo et al, 2019). Though it is still the younger more digitally literate consumer that are frequenting shopping centres less, the adoption of technology is growing beyond the younger generation (Tao et al, 2017).

The growth in FS is not distributed equally across the seven types of FS that are found in shopping centres. The categories that are have grown the most over the past five years are FastCasual, Impulse, and Gourmet Food. Fast-Casual FS has grown due to consumers looking for customized healthier meals (Mathur et al, 2019). While Impulse and Gourmet Food FS have grown due to their relatively small space requirements and the rise of 'Foodie Culture' (Cyr, et al., 2018) in North America. The current rise in FS is causing some shopping centres to lose some of their trade areas to competing shopping centres that have fewer options for FS, however that is only reflected on the current consumer behaviour for FS within shopping centres. Trade ares for the shopping centres could grow when there is further change in consumer behaviour where the consumers are going to shopping centres to dine rather than shop. While the current analysis points in that direction, the current shopping centre is still meant for shopping. With current trends the way they are, FS could be a driving factor in the near future. Shopping centres will continue to integrate FS, not just in food courts and potential food halls. Impulse and Gourmet Food units have shown that FS can be applied throughout the shopping centre. There is still potential for shopping centres to properly implement FS through understanding their individaul markets and idetnifying what consumers within their trade areas are looking for in terms of FS. While shopping centres may not be able to have every type of FS within the centre, shopping centres need to realize the repuration of their own centres and fulfill the needs of their base consumers. 


\subsection{Future Research}

There is potential to build on this research if additional data on consumer behaviour and shopping centre sales data were made available. The research undertaken in this paper leaves room to explore many different avenues with how FS impact the attraction and profitability of shopping centres. 
Appendix A - Summary Tables

Table A1 - Total Size for each FS category in 2014.

\begin{tabular}{|r|c|c|c|c|c|c|c|}
\hline Shopping Centre & Impulse & $\begin{array}{c}\text { Refuel \& } \\
\text { Relax }\end{array}$ & $\begin{array}{c}\text { Speed } \\
\text { Eating }\end{array}$ & $\begin{array}{c}\text { Fast- } \\
\text { Casual }\end{array}$ & $\begin{array}{c}\text { Casual } \\
\text { Dining }\end{array}$ & $\begin{array}{c}\text { Gourmet } \\
\text { Food }\end{array}$ & $\begin{array}{c}\text { Premium } \\
\text { Casual }\end{array}$ \\
\hline Bramalea City Centre & 1591 & 6973 & 11130 & 0 & 306 & 1936 & 9000 \\
\hline CF Eaton Centre & 2824 & 5669 & 9114 & 19444 & 6125 & 1200 & 22737 \\
\hline CF Markville & 4200 & 8619 & 5611 & 0 & 15003 & 704 & 8193 \\
\hline Erin Mills Town Centre & 2200 & 3950 & 8500 & 0 & 17143 & 1200 & 0 \\
\hline Fairview Mall & 2381 & 5917 & 7822 & 0 & 5585 & 1745 & 7306 \\
\hline Pickering Town Centre & 2150 & 5800 & 5400 & 0 & 5600 & 1700 & 0 \\
\hline $\begin{array}{r}\text { Scarborough Town } \\
\text { Centre }\end{array}$ & 3499 & 5139 & 13462 & 0 & 33556 & 3964 & 27900 \\
\hline Sherway Gardens & 1452 & 2844 & 6536 & 634 & 9147 & 1729 & 0 \\
\hline $\begin{array}{r}\text { Square One Shopping } \\
\text { Centre }\end{array}$ & 3994 & 8282 & 11330 & 14939 & 23054 & 3059 & 23277 \\
\hline Upper Canada Mall & 3288 & 4486 & 3745 & 246 & 6465 & 1252 & 0 \\
\hline $\begin{array}{r}\text { Yorkdale Shopping } \\
\text { Centre }\end{array}$ & 2379 & 3385 & 13316 & 0 & 42230 & 578 & 10854 \\
\hline
\end{tabular}

Table A2 - Total Size for Each FS category in 2019.

\begin{tabular}{|r|c|c|c|c|c|c|c|}
\hline Shopping Centre & Impulse & $\begin{array}{c}\text { Refuel \& } \\
\text { Relax }\end{array}$ & $\begin{array}{c}\text { Speed } \\
\text { Eating }\end{array}$ & $\begin{array}{c}\text { Fast- } \\
\text { Casual }\end{array}$ & $\begin{array}{c}\text { Casual } \\
\text { Dining }\end{array}$ & $\begin{array}{c}\text { Gourmet } \\
\text { Food }\end{array}$ & $\begin{array}{c}\text { Premium } \\
\text { Casual }\end{array}$ \\
\hline Bramalea City Centre & 5077 & 9194 & 12699 & 3523 & 19268 & 1971 & 9000 \\
\hline CF Eaton Centre & 4621 & 5889 & 10592 & 19357 & 6125 & 4158 & 15000 \\
\hline CF Markville & 4485 & 6139 & 5991 & 0 & 15003 & 2306 & 8193 \\
\hline Erin Mills Town Centre & 1569 & 4000 & 10330 & 4330 & 2850 & 900 & 0 \\
\hline Fairview Mall & 4259 & 6911 & 6794 & 898 & 1972 & 1858 & 0 \\
\hline Pickering Town Centre & 3050 & 4016 & 5300 & 0 & 19986 & 1900 & 5854 \\
\hline Scarborough Town & & & & & & & \\
Centre & 5749 & 7558 & 15801 & 1075 & 20905 & 3592 & 30807 \\
\hline $\begin{array}{r}\text { Square One Shopping } \\
\text { Centre }\end{array}$ & 2627 & 2739 & 4886 & 1853 & 11520 & 2998 & 27503 \\
\hline Upper Canada Mall & 4101 & 12039 & 9540 & 15665 & 60257 & 10404 & 14670 \\
\hline $\begin{array}{r}\text { Yorkdale Shopping } \\
\text { Centre }\end{array}$ & 6399 & 11219 & 10114 & 2995 & 33804 & 3813 & 36686 \\
\hline
\end{tabular}


Table A3 - Total Store Count for Each FS category in 2014

\begin{tabular}{|r|c|c|c|c|c|c|c|}
\hline Shopping Centre & Impulse & $\begin{array}{c}\text { Refuel \& } \\
\text { Relax }\end{array}$ & $\begin{array}{c}\text { Speed } \\
\text { Eating }\end{array}$ & $\begin{array}{c}\text { Fast- } \\
\text { Casual }\end{array}$ & $\begin{array}{c}\text { Casual } \\
\text { Dining }\end{array}$ & $\begin{array}{c}\text { Gourmet } \\
\text { Food }\end{array}$ & $\begin{array}{c}\text { Premium } \\
\text { Casual }\end{array}$ \\
\hline Bramalea City Centre & 6 & 6 & 23 & 0 & 0 & 2 & 2 \\
\hline CF Eaton Centre & 9 & 9 & 15 & 5 & 2 & 2 & 2 \\
\hline CF Markville & 7 & 7 & 13 & 0 & 1 & 1 & 1 \\
\hline Erin Mills Town Centre & 5 & 4 & 10 & 0 & 3 & 2 & 0 \\
\hline Fairview Mall & 6 & 4 & 13 & 0 & 2 & 2 & 1 \\
\hline Pickering Town Centre & 4 & 5 & 13 & 0 & 1 & 2 & 0 \\
\hline Scarborough Town & & & & & & & 3 \\
\hline Centre & 9 & 7 & 19 & 0 & 4 & 3 & 0 \\
\hline Square One Shopping & & 5 & 13 & 1 & 1 & 2 & 3 \\
\hline Centre & 9 & 9 & 21 & 6 & 3 & 4 & 0 \\
\hline Upper Canada Mall & 9 & 6 & 10 & 1 & 1 & 2 & \\
\hline
\end{tabular}

Table A4 - Total Store Count for Each FS category in 2019.

\begin{tabular}{|r|c|c|c|c|c|c|c|}
\hline Shopping Centre & Impulse & $\begin{array}{c}\text { Refuel \& } \\
\text { Relax }\end{array}$ & $\begin{array}{c}\text { Speed } \\
\text { Eating }\end{array}$ & $\begin{array}{c}\text { Fast- } \\
\text { Casual }\end{array}$ & $\begin{array}{c}\text { Casual } \\
\text { Dining }\end{array}$ & $\begin{array}{c}\text { Gourmet } \\
\text { Food }\end{array}$ & $\begin{array}{c}\text { Premium } \\
\text { Casual }\end{array}$ \\
\hline Bramalea City Centre & 13 & 7 & 24 & 2 & 3 & 4 & 2 \\
\hline CF Eaton Centre & 10 & 9 & 18 & 5 & 2 & 6 & 1 \\
\hline CF Markville & 7 & 5 & 14 & 0 & 1 & 3 & 1 \\
\hline Erin Mills Town Centre & 4 & 4 & 13 & 3 & 1 & 2 & 0 \\
\hline Fairview Mall & 8 & 5 & 15 & 2 & 1 & 3 & 0 \\
\hline Pickering Town Centre & 6 & 4 & 13 & 0 & 3 & 3 & 1 \\
\hline Scarborough Town & & & & & & & 4 \\
\hline Centre & 14 & 8 & 19 & 2 & 2 & 5 & 3 \\
\hline Square One Shopping & 7 & 5 & 10 & 4 & 2 & 4 & 2 \\
\hline Centre & 17 & 13 & 19 & 10 & 9 & 14 & 2 \\
\hline Upper Canada Mall & 8 & 7 & 10 & 4 & 2 & & 7 \\
\hline
\end{tabular}


Table A5 - Population of Shopping Centre Trade Areas

\begin{tabular}{|r|c|c|c|c|}
\hline & \multicolumn{2}{|c|}{2014} & \multicolumn{2}{c|}{2019} \\
\hline Shopping Centre & Primary & Secondary & Primary & Secondary \\
\hline Bramalea City Centre & 170,818 & 131,000 & 320,576 & 283,044 \\
\hline CF Eaton Centre & 543,888 & 304,968 & 410,193 & 232,631 \\
\hline Sherway Gardens* & 18,217 & 12,249 & 94,541 & 133,836 \\
\hline Erin Mills Town Centre & 75,791 & 86,874 & 79,055 & 82,594 \\
\hline CF Fairview Mall & 63,818 & 71,043 & 71,605 & 75,384 \\
\hline CF Markville & 123,759 & 80,542 & 134,956 & 95,764 \\
\hline Pickering Town Centre & 116,381 & 76,727 & 152,827 & 72,281 \\
\hline Square One Shopping & & & & \\
Centre & 373,182 & 555,620 & 312,558 & 426,439 \\
\hline Scarborough Town Centre & 281,704 & 220,374 & 292,820 & 230,508 \\
\hline Upper Canada Mall & 113,460 & 55,034 & 124,245 & 77,130 \\
\hline Yorkdale Shopping Centre & 164,461 & 237,821 & 325,021 & 460,974 \\
\hline
\end{tabular}




\section{Appendix B - Classification of Food Service Types}

Table B1 - Food Service Category Classification

\begin{tabular}{|l|l|}
\hline \multicolumn{1}{|c|}{ Store Name } & \multicolumn{1}{|c|}{ FS Category } \\
\hline A \& W & Speed Eating \\
\hline Amadeus Patisserie & Refuel \& Relax \\
\hline Amaya Express & Speed Eating \\
\hline Aroma Espresso Bar & Refuel \& Relax \\
\hline Aroma Express & Refuel \& Relax \\
\hline Arthur's Landing & Premium Casual \\
\hline Asian Gourmet & Speed Eating \\
\hline August 8 Sushi & Casual Dining \\
\hline Auntie Anne's & Impulse \\
\hline Bagel Stop & Refuel \& Relax \\
\hline Bake Three Fifty & Impulse \\
\hline Barburrito & Speed Eating \\
\hline Baroli Café & Refuel \& Relax \\
\hline Basil Box & Fast-Casual \\
\hline Baskin-Robbins & Impulse \\
\hline Baton Rouge & Premium Casual \\
\hline Bawarchi Kebab & Speed Eating \\
\hline Big Smoke Burgers & Fast-Casual \\
\hline Biryani & Speed Eating \\
\hline Blackjack BBQ & Casual Dining \\
\hline Booster Juice & Impulse \\
\hline Boston Pizza & Casual Dining \\
\hline Bourbon St Grill & Speed Eating \\
\hline Box Donuts & Impulse \\
\hline Brioche Doree & Refuel \& Relax \\
\hline Brod & Refuel \& Relax \\
\hline Bubble Tease & Impulse \\
\hline Burger King & Speed Eating \\
\hline Cacao 70 & Refuel \& Relax \\
\hline California Thai & Speed Eating \\
\hline Canyon Creek & Premium Casual \\
\hline Caribbean Queen & Speed Eating \\
\hline Casey's Bar and Grill & Casual Dining \\
\hline Charley's Philly Steak & Speed Eating \\
\hline Chatime & Impulse \\
\hline & \\
\hline
\end{tabular}




\begin{tabular}{|c|c|}
\hline Cheesecake Factory & Casual Dining \\
\hline Chipotle & Fast-Casual \\
\hline Chocollata Goutmet & Gourmet Foods \\
\hline Cheese & Gourmet Foods \\
\hline Cinnabon & Impulse \\
\hline Cob's Bread & Gourmet Foods \\
\hline Coco Bubble Tea & Impulse \\
\hline Country Style & Refuel \& Relax \\
\hline Country Style Bistro & Refuel \& Relax \\
\hline Craft Chippery & Gourmet Foods \\
\hline Crepe De Licious & Impulse \\
\hline Cultures & Fast-Casual \\
\hline Dairy Queen / Orange Julius & Impulse \\
\hline Dal Moro & Fast-Casual \\
\hline Danish Pastry House & Refuel \& Relax \\
\hline David Tea & Refuel \& Relax \\
\hline Delight Chocolates & Gourmet Foods \\
\hline Earls & Premium Casual \\
\hline East Side Mario's & Casual Dining \\
\hline Edo Japan & Speed Eating \\
\hline Eva's Chimneys & Impulse \\
\hline Eva's Original Chimney & Impulse \\
\hline Freshii & Fast-Casual \\
\hline Freshly Squeezed & Impulse \\
\hline Froshberg Gelato & Impulse \\
\hline Hero Burger & Speed Eating \\
\hline Ichiban Sushi & Casual Dining \\
\hline Jamba Juice & Impulse \\
\hline Joey Markville & Premium Casual \\
\hline Joey's & Premium Casual \\
\hline Jugo Juice & Impulse \\
\hline Kernels Popcorn & Gourmet Foods \\
\hline KFC & Speed Eating \\
\hline KFC/Taco Bell & Speed Eating \\
\hline Kiki's Funnel Cake & Speed Eating \\
\hline Kin Kin Bakery & Refuel \& Relax \\
\hline Kiung Pow Wok & Speed Eating \\
\hline Koryo Korean BBQ & Speed Eating \\
\hline Koya Japan/Koya Japon & Speed Eating \\
\hline Kung Pao Wok & Speed Eating \\
\hline Kwan Dim Sum & Premium Casual \\
\hline La Carnita \& Sweet Jesus & Casual Dining \\
\hline La Paloma & Impulse \\
\hline
\end{tabular}




\begin{tabular}{|l|l|}
\hline La Prep & Casual Dining \\
\hline Laduree & Refuel \& Relax \\
\hline Laura Secord & Gourmet Foods \\
\hline Liberty Noodle & Speed Eating \\
\hline Lindt Chocolate & Gourmet Foods \\
\hline Love Me Sweet & Impulse \\
\hline Macaron Boutique & Impulse \\
\hline Machhu Wok & Speed Eating \\
\hline Mac's Sushi & Speed Eating \\
\hline Made In Japan, A Teriyaki Experience & Speed Eating \\
\hline Manchu Wok & Speed Eating \\
\hline Marble Slab & Impulse \\
\hline Ma's Best Quality Shop & Fast-Casual \\
\hline Mcdonald's & Speed Eating \\
\hline Michael's Baguette & Refuel \& Relax \\
\hline Mii Sandwich Co & Speed Eating \\
\hline Mii/Chatime & Speed Eating \\
\hline Milestone & Casual Dining \\
\hline Milestone's & Casual Dining \\
\hline mmmuffins & Refuel \& Relax \\
\hline Moxie & Premium Casual \\
\hline Moxies & Premium Casual \\
\hline Moxies Classic Grill & Premium Casual \\
\hline Mr Pretzel & Impulse \\
\hline Mr Sub & Speed Eating \\
\hline Mrs Fields & Impulse \\
\hline Mrs Fields/Pretzelmaker & Impulse \\
\hline Mrs Vanelli's & Speed Eating \\
\hline Mrs. Field's Cookies & Impulse \\
\hline Mrs. Vanelli's Fresh Italian Foods/Mme. & Speed Eating \\
\hline Van & \\
\hline Mucho Burrito & Fast-Casual \\
\hline Naan \& Kabob & Speed Eating \\
\hline Nadege & Impulse \\
\hline Nestle Café & Refuel \& Relax \\
\hline New York Fries & Speed Eating \\
\hline Open Kitchens - Richtreee & Fast-Casual \\
\hline Orange Julius & Impulse \\
\hline Osmows & Fast-Casual \\
\hline Pablo Cheesetart & Impulse \\
\hline Pi Co & Fast-Casual \\
\hline Pickle Barrel & Casual Dining \\
\hline Pickle Barrel Grand & Casual Dining \\
\hline
\end{tabular}




\begin{tabular}{|c|c|}
\hline Pier 81 & Casual Dining \\
\hline Pier 87 & Casual Dining \\
\hline Pinkberry & Impulse \\
\hline Plancha & Fast-Casual \\
\hline Pretzelmarker & Impulse \\
\hline Purdys Chocolatier & Gourmet Foods \\
\hline Rainforest Café & Casual Dining \\
\hline Real Fruit Bubble Tea & Impulse \\
\hline Reds & Casual Dining \\
\hline Refuel Juciery & Impulse \\
\hline RH Courtyard Café & Premium Casual \\
\hline Richtree Natural Market & Fast-Casual \\
\hline Rocky Mountain Chocolate Factory & Gourmet Foods \\
\hline Ruby Thai & Speed Eating \\
\hline Ruby Thai Kitchen & Speed Eating \\
\hline Sansotei Ramen & Casual Dining \\
\hline Sbarro & Speed Eating \\
\hline Second Cup & Refuel \& Relax \\
\hline Seed to Sausage & Premium Casual \\
\hline Shanghai 360 & Speed Eating \\
\hline Sizzling Wok & Speed Eating \\
\hline South St Burger Co & Speed Eating \\
\hline Spring Rolls & Casual Dining \\
\hline Squish & Gourmet Foods \\
\hline St Louis Bar and Grill & Casual Dining \\
\hline Starbucks Coffee & Refuel \& Relax \\
\hline SU \& BU & Fast-Casual \\
\hline Su \& Shi & Speed Eating \\
\hline Subway & Speed Eating \\
\hline Sugar King Factory & Gourmet Foods \\
\hline Sugar Mountain & Gourmet Foods \\
\hline Sugarfina & Gourmet Foods \\
\hline Sushi Q & Speed Eating \\
\hline Sushi Shop & Speed Eating \\
\hline Sweet Jesus & Impulse \\
\hline Sweet Tooth & Gourmet Foods \\
\hline Swiss Chalet & Casual Dining \\
\hline Szechuan Express & Speed Eating \\
\hline Taco Bell & Speed Eating \\
\hline Taco Bell/KFC Express & Speed Eating \\
\hline Tao Ltea Leaf & Refuel \& Relax \\
\hline Teavana & Refuel \& Relax \\
\hline Ten Ren Tea Time & Impulse \\
\hline
\end{tabular}




\begin{tabular}{|l|l|}
\hline Teopia & Refuel \& Relax \\
\hline Teriyaki Experience & Speed Eating \\
\hline Thai Express & Speed Eating \\
\hline The Alley & Impulse \\
\hline The Keg & Premium Casual \\
\hline The Pie Guys & Speed Eating \\
\hline The Second Cup & Refuel \& Relax \\
\hline Tiki Ming & Speed Eating \\
\hline Tim Horton's & Refuel \& Relax \\
\hline Timothys & Refuel \& Relax \\
\hline Timothy's Coffees of the World & Refuel \& Relax \\
\hline Tipsy Treats & Gourmet Foods \\
\hline Tora & Premium Casual \\
\hline Trattoria Mercatto & Casual Dining \\
\hline Tropical Joe' & Speed Eating \\
\hline Tropical Joe's & Speed Eating \\
\hline Tsujiri & Refuel \& Relax \\
\hline Umi Sushi And Teriyaki & Speed Eating \\
\hline Umi Sushi Express & Speed Eating \\
\hline Union Chicken & Casual Dining \\
\hline Union Chicken/Amano & Casual Dining \\
\hline Valentino & Speed Eating \\
\hline Vanelli's & Speed Eating \\
\hline Villa Medina & Speed Eating \\
\hline Village Juicery & Refuel \& Relax \\
\hline Wasabi & Speed Eating \\
\hline Yogen Fruz & Impulse \\
\hline Yogurtyme & Impulse \\
\hline Yoi Ramen Eatery & Speed Eating \\
\hline & \\
\hline
\end{tabular}




\section{References}

20 Vic Management. (2014). Erin Mills Town Centre Siteplan. 20 Vic Management.

20 Vic Retail. (2014). Pickering Town Centre. Toronto: 20 Vic Management.

Aburi Restaurant's. (2019). Concepts. Retrieved from Aburi Restaurant's: https://aburirestaurants.com/concepts/

Berry, L. L., Seiders, K., \& Grewal, D. (2002). Understanding the Service Convience. Journal of Marketing, 66(3), 1-17. Retrieved from https://www.jstor.org/stable/3203451

Brod. (2019). Our Story. Retrieved from Brod.

Cadillac Fairview. (2014). CF Markville. Cadillac Fairview.

Cadillac Fairview. (2014). CF Toronto Eaton Centre Siteplan. Cadillac Fairview.

Cadillac Fairview. (2014). Sherway Gardens Siteplan. Cadillac Fairview.

Cadillac Fairview. (2019). CF Markville. Cadillac Fairview.

Cadillac Fairview. (2019). CF Toronto Eaton Centre Siteplan. Toronto: Cadillac Fairview.

Cadillac Fairview. (2019). Dining \& Entertainment. Retrieved from CF Toronto Eaton Centre: https://www.cfshops.com/toronto-eaton-centre/dining-entertainment.html\#restaurants

Cadillac Fairview. (2019). Sherway Gardens Siteplan. Cadillac Fairview.

Chebat, J.-C., Michon, R., Narjes, H.-S., \& Oliveira, S. (2014). The effects of mall renovation on shopping values, satisfaction and spending behaviour. Journal of Retalling and Consumer Servies, 21(4), 610-618.

Chef Academy. (2019). Retrieved from Assembly Chefs Hall: https://www.assemblychefshall.com/chefs

Clay, C. (2017, July 19). Multi-million-dollar renovation of Erin Mills Town Centre nearing completion. Retrieved from Mississauga: https://www.mississauga.com/newsstory/7461436-multi-million-dollar-renovation-of-erin-mills-town-centre-nearingcompletion/

Cushman \& Wakefield. (2016). Food Halls of America. Cushman \& Wakefield.

Cushman \& Wakefield. (2019). Erin Mills Town Centre Siteplan. Cushman \& Wakefield.

Cushman \& Wakefield. (2019). Food Hall 3.0 - The Revolution Continues. Cushman \& Wakefield.

Cyr, A., MsCosker, A., Vassallo, A. J., Kelly, B., Zhang, L., Wang, Z., . . Freeman, B. (2018). Junk Food Markeitng on Instagram: Content Analysis. JMIR Public Health and Surveillance, $4(2)$. 
Daniel, C., \& Hernandez, T. (2018). CSCA Retail 100. Toronto: Centre for the Study of Commercial Activities.

Diaz, M. R., \& Acuna, J. L. (2015). Locating a supermarket using locally calibrated Huff model. International Journal of Geographical Information Science, 217-233.

Doub, A. E., Levin, A., Health, C. E., \& LeVangie, K. (2015). Mobile app-etite: Consumerattitudes towards and use ofmobile technology in the contextof eating behaviour. Journal of Direct, Data and Digital Marketing Practice(17), 114-129.

Duncan, H., Travis, S., \& McAuley, W. (1995). An Emergent Theoretical Model for Interventions Encouraging Physical Activity (Mall Walking) Among Older Adults. The Journal of Applied Gerontology, 14(1), 64-77.

Environics Analytics. (2014). Release Notes - DemoStats 2014. Toronto: Environics Analytics.

Environics Analytics. (2018). FoodSpend Release Notes. Toronto: Environics Analytics.

Environics Analytics. (2019). HouseholdSpend. Retrieved from Environics Analytics: https://www.environicsanalytics.com/en-ca/data/financial-databases/householdspend

Environics Analytics. (2019). Who We Are. Retrieved from Environics Analytics: https://www.environicsanalytics.com/en-ca/about/why-us

ESRI. (n.d.). How Original Huff Model works. Retrieved from ArcGIS Desktop : https:/desktop.arcgis.com/en/arcmap/10.3/tools/business-analyst-toolbox/how-originalhuff-model-works.htm

Gracia, A., \& Magistris, T. d. (2007). Organic food product purchase behaviour: a pilot study for urban consumers in the South of Italy. Spanish Journal of Agricultural Research, 5(4), $439-451$.

Great Speculations. (2018, October 19). Can McDonald's Technology Initiatives Help Improve The A verage Order Size In The Third Quarter? Retrieved from Forbes: https://www.forbes.com/sites/greatspeculations/2018/10/19/can-mcdonalds-technologyinitiatives-help-improve-the-average-order-size-in-the-third-quarter/\#1cdc70734cb6

Grybś, M. K. (2018). The scent marketing: consumers perception. The Business \& Management Review, 8(4), 483-486.

Harris, S. (2019, July 28). Plant-based eggs join meatless options at Tim Hortons. Retrieved from CBC: https://www.cbc.ca/news/business/tim-hortons-a-w-beyond-meat-egg-plantbased-1.5227188

Hempel, C., \& Hamm, U. (2016). How important is local food to organic-minded consumers? Appetite, 96(1), 309-318.

Hernandez, T., Lea, T., \& Bermingham, P. (2004). What's in a Trade Area? Toronto: Centre for the Study of Commercial Activites. 
Holton, R. H. (1958). The Distinction between Convenience Goods, Shopping Goods, and Specialty Goods. Journal of Marketing, 23(1), 53-56. Retrieved from https://www.jstor.org/stable/1248017

Huff, D. L. (1964). Defining and Estimating a Trading Area. Journal of Marketing, 28(3), 34-38.

ICSC. (2017). The Successful Integration of Food \& Beverage Within Retail Real Estate. New York: ICSC.

International Council of Shopping Centres. (2016). Shopping Centers Becoming Consumer Centers. International Coucil of Shopping Centres.

JLL Foodservice Consulting. (2019). Foodservice Trends 2019. London: JLL.

Kunbo, S., Jonas, V. D., Yang, Y., \& Frank, W. (2019). Does e-shopping replace shopping centre trips? Empirical evidence from Chengdu, China. Transporation Research Part A, 21-33.

Kusumasondjaja, S., \& Tjiptono, F. (2018). Endorsement and Visual complexity in food advertising on Instagram. Endorsement and Visual Complexity.

Lasaleta, J. D., \& Redden, J. P. (2018). When promoting similarity slows satiation. Journal of Marketing Research, 55(3), 446-457.

Lin, T., Xia, J., Robinson, T. P., Olaru, D., Smith, B., Taplin, J., \& Cao, B. (2016). Enhanced Huff model for estimating Park and Ride (PnR) catchment areas in Perth, WA. Journal of Tranport Geography, 54, 336-248.

Luo, J. (2014). Integrating the Huff Model and Floating Catchment Area Methods to Analyze Spatial Access to Healthcare Services. Transaction in GIS, 18(3), 436-448.

Mathur, T., \& Gupta, A. (2019). THE IMPACT OF DINING ATMOSPHERICS AND PERCEIVED FOOD QUALITY ON CUSTOMERS' RE-PATRONAGE INTENTION IN FAST CASUAL RESTAURANTS. Tourism and Hospitality Management, 25(1), 125.

Morguard. (2014). Bramalea City Centre Siteplan. Morguard.

Morguard. (2019). Bramalea City Centre. Retrieved from Morguard: https://www.morguard.com/news-knowledge/case-studies/bramalea-city-centre

Morguard. (2019). Bramalea City Centre Siteplan. Morguard.

Nagpal, A., Lei, J., \& Khare, A. (2012). Food Customization: How Decision Frame Influences Choice. Advances in Consumer Research, 40, 849-850.

Oxford Properties. (2017). Yorkdale Shopping Centre - Economic Impact Analysis, Toronto, Ontario. Toronto: Urban Metrics Inc.

Oxford Properties. (2019). Square One Shopping Centre Siteplan. Oxford Properties. 
Oxford Properties. (2019). Taste Markt. Retrieved from STC:

https://scarboroughtowncentre.com/store-category/taste-mrkt/

Oxford Properties. (2019). Upper Canada Mall Siteplan . Oxford Properties.

Palmieri, C. (2018, August 8). The Sweet Success of Sugarfina. Retrieved from Total Retail: https://www.mytotalretail.com/article/the-sweet-success-of-sugarfina/

Patterson, C. (2018, September 11). Inside Market \& Co., a First-to-Canada Large-Format MallBased Food Market Concept [Photos]. Retrieved from Retail Insider: https://www.retailinsider.com/retail-insider/2018/9/market-and-co-newmarket-upper-canada-mall-oxfordproperties

Pine, R., \& Johns, N. (2002). Consumer behaviour in the food service industry: A review. Hospitality Management, 21, 119-134.

Plancha. (2019). Plancha. Retrieved from Plancha: https://www.planchatoronto.ca/

Porral, C. C., \& Mangin, J. P. (2016). Specialty food retailing: The role of purchase frequency and determinants of customer satisfaction and loyalty. British Food Journal, 2798-2814.

Reel, J. J. (2017). Why Eating is Important in our Everyday Lives. In J. J. Reel, Filing up: The Psychology of eating (p. 29). Santa Barbara, California, United States of America: ABCCLIO, LLC.

Reilly, W. J. (1929). Methods for the Study of Retail Relationships. University of Texas Bulletin, $4(4), 7-48$.

Retail Council of Canada. (2018). Canadian Shopping Centre Study 2018. Toronto: Retail Council of Canada.

Retail Insider. (2017, April 5). Oxford Properties Launches Innovative 'CONCEPT' Retail Space [Photos]. Retrieved from Retail Insider: https://www.retail-insider.com/retailinsider/2017/4/concept-yorkdale

Ristino, L. (2013). Back to the New: Millennials and the Sustainable Food Movement. Vermont Journal of Environmental Law, 1-31.

Robinson, T. B., Backholer, K., \& Peeters, A. (2016). Digital marketing of unhealthy foods to Australian children and adolescents. Health Promotion International, 31(3), 523-533.

Singla, V., \& Rai, H. (2018). Examining the Effectiveness of Huff Model in Store Assessment. Jindal Journal of Business Research, 7(2), 122-134.

Sosianika, A., Suhartanto, D., Chen, B. T., \& Mohi, Z. (2019). Exploring loyalty to specialty foods among tourists and residents. British Food Journal, 120(5), 1120-1131.

Square One. (2019). Merchants \& Restaurants. Retrieved from The Food District: https://shopfooddistrict.com/merchants/ 
Statistics Canada. (2018, September 17). Census Tract (CT). Retrieved from Statistics Canada: https://www150.statcan.gc.ca/n1/pub/92-195-x/2011001/geo/ct-sr/ct-sr-eng.htm

Statistics Canada. (2019, February 20). Focus on Geography Series, 2016 Census. Retrieved from Statistics Canada: https:/www12.statcan.gc.ca/census-recensement/2016/assa/fogs-spg/Facts-cma-eng.cfm?LANG $=$ Eng\&GK $=\mathrm{CMA} \& \mathrm{GC}=535 \& \mathrm{TOPIC}=1$

Statistiics Canada. (2017, July 1). Annual Demographic Estimates: Subprovincial Areas, July 1, 2017. Retrieved from Statistics Canada: https:/www150.statcan.gc.ca/n1/pub/91-214$\mathrm{X} / 2018000 /$ section01-eng.htm

Tao, D., Chang, Y. H., Chiu, C. J., \& Liu, C. W. (2017). Understanding Older Adult's Technology Adoption and Withdrawal for Elderly Care and Education: Mixed Method Analysis from National Survey. Journal of Medical Internet Research, 19(11). doi:10.2196/jmir.7401

Tao, Z., Yao, Z., Kong, H., \& Guicai, L. (2018). Spatial accessibility to healthcare services in Shenzhen, China: improving the multi-modal two-step floating catchment area method by estimating travel time via online map APIs. BMC health services research, 345. doi:10.1186/s12913-018-3132-8

Taylor, K. (2018, January 18). Starbucks is the latest victim of the retail apocalypse. Retrieved from Business Insider: https://www.businessinsider.com/teavanas-stores-closing-2018-1

The Economist. (2015, January 10). Better burgers, choicer chicken; Fast-casual restaurants. The Economist, 414(8920), p. 56.

Tobler, W. (1970). A computer movie simulating urban growth in the Detroit region. Economic Geography, 234-240.

Wolfinbarger, M., \& Gilly, M. C. (2001). Shopping Online for Freedom, Control, and Fun. California Management Review, 43(2), 34-55.

Калініна, О. С., \& Байцар, Р. І. (2016). Aesthetic indicators of packaging quality. ScienceRise, $11(0), 33-43$. 